\title{
Gender difference in the activity but not expression of estrogen receptors $\alpha$ and $\beta$ in human lung adenocarcinoma cells
}

\author{
Susan M Dougherty ${ }^{1}$, Williard Mazhawidza ${ }^{1}$, Aimee R Bohn ${ }^{1}$, \\ Krista A Robinson ${ }^{1}$, Kathleen A Mattingly ${ }^{1}$, Kristy A Blankenship ${ }^{1}$, \\ Mary O Huff ${ }^{2}$, William G McGregor ${ }^{3}$ and Carolyn M Klinge ${ }^{1}$
}

\footnotetext{
${ }^{1}$ Department of Biochemistry and Molecular Biology, University of Louisville School of Medicine, Louisville, KY 40292, USA ${ }^{2}$ Department of Biology, Bellarmine University, Louisville, KY 40205, USA

${ }^{3}$ Department of Pharmacology and Toxicology, Center for Genetics and Molecular Medicine, University of Louisville School of Medicine, Louisville, KY 40292, USA
}

(Requests for offprints should be addressed to C M Klinge; Email: carolyn.klinge@louisville.edu)

\begin{abstract}
The higher frequency of lung adenocarcinoma in women smokers than in men smokers suggests a role for gender-dependent factors in the etiology of lung cancer. We evaluated estrogen receptor (ER) $\alpha$ and $\beta$ expression and activity in human lung adenocarcinoma cell lines and normal lung fibroblasts. Full-length $E R \alpha$ and $E R \beta$ proteins were expressed in all cell lines with higher ER $\beta$ than $E R \alpha$. Although estradiol $\left(E_{2}\right)$ binding was similar, $E_{2}$ stimulated proliferation only in cells from females, and this response was inhibited by anti-estrogens 4-hydroxytamoxifen (4-OHT) and ICl 182,780 . In contrast, $E_{2}$ did not stimulate replication of lung adenocarcinoma cells from males and $4-\mathrm{OHT}$ or $\mathrm{ICl}$ did not block cell proliferation. Similarly, transcription of an estrogen response element-driven reporter gene was stimulated by $E_{2}$ in lung adenocarcinoma cells from females, but not males. Progesterone receptor (PR) expression was increased by $E_{2}$ in two out of five adenocarcinoma cell lines from females, but none from males. $E_{2}$ decreased $E$-cadherin protein expression in some of the cell lines from females, as it did in MCF-7 breast cancer cells, but not in the cell lines from males. Thus, ER $\alpha$ and ER $\beta$ expression does not correlate with the effect of ER ligands on cellular activities in lung adenocarcinoma cells. On the other hand, coactivator DRIP205 expression was higher in lung adenocarcinoma cells from females versus males and higher in adenocarcinoma cells than in normal human bronchial epithelial cells. DRIP205 and other ER coregulators may contribute to differences in estrogen responsiveness between lung adenocarcinoma cells in females and males.
\end{abstract}

Endocrine-Related Cancer (2006) 13 113-134

\section{Introduction}

While the number of women dying as a result of metastatic breast and colon cancer is declining, the mortality associated with lung and bronchus cancer in females continues to rise (Greenlee et al. 2000). Lung cancer is the leading cause of cancer death in both women and men in the United States (Patel et al. 2004). Despite advances in chemotherapy for treating lung cancer, the 5-year survival rate has not increased significantly over the last 25 years, remaining at approximately $14 \%$ (Williams \& Sandler 2001). The 2-fold higher frequency of lung cancer in women smokers than in men smokers (Shields 2000) strongly suggests the involvement of gender-dependent factors in the etiology of lung cancer (Omoto et al. 2001). Despite smoking for shorter periods of time, with fewer cigarettes per day and inhaling less deeply than men, women have a higher incidence of lung cancer, notably lung adenocarcinoma, a type of non-small cell lung cancer (NSCLC) (Stabile \& Siegfried 2003). In addition, women non-smokers are at a 2.5 -fold greater risk than male non-smokers for developing lung adenocarcinoma (Siegfried 2001). 
The mechanisms underlying the gender difference in NSCLC incidence is likely to be multifactorial. For example, women are more susceptible to smokinginduced DNA damage than men (Stabile \& Siegfried 2003). However, mutations of p53 and K-ras that are regarded as early events in carcinogenesis are rarely found in adenocarcinomas, which account for $75 \%$ of lung cancer in females (Hashimoto et al. 2000). Three of the nine adenocarcinoma cell lines used in this study have activating K-ras mutations, but no genderdependent differences were apparent in this small sample. Differences in the expression, gene polymorphisms and activity of phase I (e.g. CYP1A1 (Mollerup et al. 1999)) and II drug metabolizing enzymes (e.g. glutathione-S-transferase (GST) and $N$ acetyltransferase (NAT) (Stabile \& Siegfried 2003)), may play a role in gender differences. Interestingly, over-expression of the protooncogene c-erbB2/HER2/ neu, a ligand-independent epidermal growth factor receptor, is associated with poor prognosis in NSCLC (Gatzemeier et al. 2004) as well as breast cancer (Pegram et al. 1998).

The gender differences in adenocarcinoma implicate hormones in lung cancer risk. Estrogens increase the risk of breast cancer (Wolff et al. 1996) and oral contraceptive therapy (OCT) is protective against ovarian and endometrial cancer (Boyle et al. 2000). However, the role of estrogen in lung cancer is unclear. Some studies, reviewed by Stabile and Siegfried (2003), indicate a role for estrogen in lung cancer risk. For example, one study noted a positive correlation between post-menopausal estrogen replacement therapy, smoking and lung adenocarcinoma (Taioli \& Wynder 1994). A role for estrogen in the etiology of squamous cell carcinoma (SCC) in a Chinese population was suggested by a correlation between SCC and a higher number of menstrual cycles (Liao et al. 1996). Likewise, a large clinical trial in breast cancer patients showed that more women taking the antiestrogen tamoxifen had a second primary non-breast cancer, including lung cancer, compared with those taking the aromatase inhibitor exemestane, although the differences were not statistically significant (Coombes et al. 2004). On the other hand, the higher survival rates for women than men with NSCLC in a study of 14676 women may indicate a protective effect of estrogen (Moore et al. 2003). Indeed, a recent study reported that post-menopausal users of hormone replacement therapy (HRT) were at lower risk of developing lung cancer and that the protective effect of HRT was mainly observed in current smokers who were also the 'lightest smokers', i.e. $<22$ packyears (Schabath et al. 2004). Clearly, further studies are needed to investigate the role of estrogens in lung cancer risk.

Estrogens exert their molecular action by interaction with two subtypes of estrogen receptor (ER), ER $\alpha$ and ER $\beta$. In the original characterization of $E R \alpha$ and ER $\beta$ mRNA tissue distribution, in rats, ER $\beta$ was predominant in lung (Kuiper et al. 1997). There was no reported lung phenotype for ER $\alpha$ null ( $\alpha$ ERKO) mice (Couse et al. 1997, Rubanyi et al. 1997), but a comparison of the lungs of wild-type (wt) versus ER $\beta$ null ( $\beta E R K O)$ mice revealed decreased numbers of alveoli in adult female ER $\beta-/-$ mice (Patrone et al. 2003). Lungs of female $\beta E R K O$ mice also showed decreased surfactant, platelet-derived growth factor A (PDGF-A), and granulocyte-macrophage colonystimulating factor (GM-CSF), indicating that ER $\beta$ plays a role in lung homeostasis in mice (Patrone et al. 2003). Immunohistochemical staining revealed ER $\beta$ expression in human lung in columnar epithelium and in intermediate, basal and smooth muscle cells whereas ER $\alpha$ was expressed in basal and smooth muscle cells (Taylor \& Al-Azzawi 2000). ER $\alpha$ and ER $\beta$ have been proposed to play opposite roles, i.e. 'yin and yang', in cell proliferation with ER $\alpha$ being proliferative and ER $\beta$ anti-proliferative (Lindberg et al. 2003). For example, ER $\alpha$ expression is increased in breast cancer and over-expression of ER $\beta$ inhibits estradiol $\left(\mathrm{E}_{2}\right)$-stimulated breast cancer cell proliferation (Paruthiyil et al. 2004). Whether the ER $\alpha$ : ER $\beta$ ratio increases in lung cancer is unknown.

There are a limited number of studies with conflicting data regarding $E R \alpha$ and $E R \beta$ expression in human lung cancer and in lung cancer cell lines (Croxtall et al. 1994, Caltagirone et al. 1997, Omoto et al. 2001, Radzikowska et al. 2002, Stabile et al. 2002, 2005, Hershberger et al. 2005) and only two studies directly comparing ER expression in lung cancer specimens and cell lines in males and females (Fasco et al. 2002, Mollerup et al. 2002). One study reported similar levels of ER $\alpha$ and ER $\beta$ in females and males (Mollerup et al. 2002). In contrast, another group reported higher $E R \alpha$ expression in females than in males whereas ER $\beta$ expression was similar (Fasco et al. 2002). A general conclusion from these reports is that lung tumors from women are more likely to express ER $\alpha$ than tumors from men, with ranges from $7-97 \%$ by immunohistochemistry (IHC), and that 'the potential role of estrogens in lung cancer is understudied' (Patel 2005).

It is well-established that $\mathrm{E}_{2}$ stimulates the proliferation of estrogen-responsive tissues and cell lines, e.g. human breast and endometrial cells. In contrast to the many inconsistent reports on ER expression, there are only four reports examining the functional 
Table 1 Characteristics of the human non-small cell lung cancer (NSCLC) cell lines used in this report. All cell lines were obtained from ATCC Manasas, VA, USA

\begin{tabular}{|c|c|c|c|c|}
\hline Cell line & $\begin{array}{l}\text { Sex of } \\
\text { patient }\end{array}$ & $\begin{array}{l}\text { Smoker/non- } \\
\text { smoker (NS) }\end{array}$ & Reported ER status (reference) & $\begin{array}{l}\text { K-ras mutation } \\
\text { (codon GGT-GTT; aa G12C) } \\
\text { (http://www.sanger.ac.uk, } \\
\text { unless otherwise indicated) }\end{array}$ \\
\hline A549 & male & unknown & $\begin{array}{l}\text { - no ER } \alpha \text { (Croxtall et al., 1994) } \\
\text { - Low ER } \alpha \text { and high ER } \beta \\
\text { (Stabile et al., 2002) } \\
\text { - No ER } \alpha, \text { but ER } \beta \text { (Hershberger et al., 2005) }\end{array}$ & $\begin{array}{l}\text { K-ras point mutation } \\
\text { (Okudela et al., 2004) }\end{array}$ \\
\hline $\mathrm{NCl}-\mathrm{H} 23$ & male & smoker & $\begin{array}{l}\text { - Low ER } \alpha \text { and high ER } \beta \text { (Stabile et al., 2002) } \\
\text { - ER } \alpha \text { and ER } \beta \text { (Pietras et al., 2005) }\end{array}$ & $\begin{array}{l}\text { K-ras point mutation } \\
\text { (ATCC information) }\end{array}$ \\
\hline $\mathrm{NCl}-\mathrm{H} 1299$ & male & smoker & & $\begin{array}{l}\text { No K-ras mutation, } \\
\text { but mutant } \mathrm{N} \text {-ras }\end{array}$ \\
\hline $\mathrm{NCl}-\mathrm{H} 1792$ & male & smoker & & K-ras point mutation \\
\hline $\mathrm{NCl}-\mathrm{H} 1395$ & female & smoker & & No K-ras mutation \\
\hline $\mathrm{NCl}-\mathrm{H} 1435$ & female & NS & $\begin{array}{l}\text { - } \mathrm{ER} \beta>\mathrm{ER} \alpha \text { (Mollerup et al., 2002) } \\
\text { - } \mathrm{ER} \alpha ;<10 \% \text { of the level of } \mathrm{ER} \alpha \text {; in MCF-7 } \\
\text { cells (Mollerup et al., 2002) }\end{array}$ & No K-ras mutation \\
\hline $\mathrm{NCl}-\mathrm{H} 1793$ & female & NS & & No K-ras mutation \\
\hline $\mathrm{NCl}-\mathrm{H} 1944$ & female & smoker & & K-ras mutation \\
\hline $\mathrm{NCl}-\mathrm{H} 2073$ & female & smoker & & No K-ras mutation \\
\hline
\end{tabular}

consequences of ER expression in lung adenocarcinoma cell lines (Stabile et al. 2002, 2005, Hershberger et al. 2005, Pietras et al. 2005). The studies revealed that $\mathrm{E}_{2}$ stimulated proliferation of lung adenocarcinoma cell lines from males, e.g. NCI-H23 (Table 1), in vitro in an ER-dependent manner (Stabile et al. 2002, 2005, Pietras et al. 2005) and one study reported that $E_{2}$ increased E-cadherin and Id-2 expression in $201 \mathrm{~T}$ cells, also from males (Hershberger et al. 2005). The variability of $\operatorname{ER} \alpha$ and $\operatorname{ER} \beta$ expression between studies and the paucity of functional studies on ER in lung adenocarcinoma indicate that more information is needed to determine the significance and role of these receptors in NSCLC. In particular, no one has directly compared the effect of $\mathrm{E}_{2}$ and anti-estrogens on the proliferation or estrogenic responses of lung adenocarcinoma cell lines from male versus females in a side-by-side comparison.

In this study, we used nine different human adenocarcinoma cell lines from male or female lung cancer patients to test their estrogen responsiveness. We demonstrate that the human adenocarcinoma cell lines, a normal human lung fibroblast cell line (NF1604), and normal human bronchial epithelial (NHBE) cells express ER $\alpha$ and $\mathrm{ER} \beta$ proteins. Although no differences in the levels of $\mathrm{ER} \alpha$ and ER $\beta$ proteins or in $\left[{ }^{3} \mathrm{H}\right] \mathrm{E}_{2}$ binding in cells from males or females were detected, there were significant differences in cellular biochemical responses to $E_{2}$ and the anti-estrogens 4-hydroxytamoxifen (4-OHT) and ICI 182,780 between cell lines from males and females. Whereas the proliferation of the cell lines from females was stimulated by $\mathrm{E}_{2}$ and blocked by concomitant administration of 4-OHT or ICI 182,780, the cell lines from males were non-responsive to these treatments. Similar results were detected at the transcriptional level. Although other investigators have demonstrated responses of lung adenocarcinoma cell lines from males to selective ER modulators (SERMs) including fulvestrant (Stabile et al. 2002, 2005, Hershberger et al. 2005), our data support the possible use of SERMs such as tamoxifen or fulvestrant (ICI 182,780) for selectively treating women with lung adenocarcinomas, although further studies will be needed to extend these suggestions.

\section{Materials and methods}

\section{Chemicals}

$\mathrm{E}_{2}$ and 4-hydroxytamoxifen (4-OHT) were purchased from Sigma. ICI 182,780, 4,4',4"-(4-propyl-[1H]pyrazole-1,3,5-triyl)trisphenol (PPT, an ER $\alpha$-selective agonist) and 2,3-bis(4-hydroxyphenyl)-propionitrile (DPN, an ER $\beta$-selective agonist) were purchased from Tocris (Ellisville, MO, USA). The $R, R$ enantiomer of 5,11-cis-diethyl-5,6,11,12-tetrahydrochrysene-2,8-diol (R,R-THC) was generously provided by Dr J A Katzenellenbogen of the University of Illinois (Sun et al. 1999). 


\section{Cell lines}

A549, NCI-H23, NCI-H1299, NCI-H1395, NCIH1435, NCI-H1792, NCI-H1793, NCI-H1944, NCIH2073 and MCF-7 cell lines were purchased from ATCC (Manasas, VA, USA) and were maintained in the recommended media and supplements. The characteristics of the lung adenocarcinoma cell lines are listed in Table 1. The primary fibroblast cell strain GM1604 (Coriell Institute, Camden, NJ, USA) was originally derived from human fetal lung tissue, and was immortalized by expression of the catalytic subunit of human telomerase (hTERT), under a license from Geron Corporation (Menlo Park, CA, USA), by Dr L McDaniels (University of Texas Southwestern Medical Center, Dallas, TX, USA) and named NF1604. The cells were karyotyped and found to be 46XY (Ouellette et al. 2000). They were provided to W G M by Dr McDaniels under the terms of Material Transfer Agreement 3025 between W G M and Geron Corporation. NHBE cells were purchased from Cambrex (Walkersville, MD, USA) and maintained in bronchial epithelial growth medium supplemented with BulletKit growth factors (Cambrex).

\section{Cell proliferation/MTT assay}

Cell proliferation was determined using the Cell Proliferation Kit 1 (MTT) (Roche) and Cell Titer 96 AQueous One solution cell proliferation assays (Promega) according to the manufacturers' protocols. Briefly, $2 \times 10^{3}$ cells were plated per well in 96-well plates in phenol-red-free media containing $10 \%$ dextran-coated charcoal-stripped fetal bovine serum (DCC-FBS) for $24 \mathrm{~h}$ prior to treatment. The cells were treated with ethanol $(\mathrm{EtOH})$, ICI 182,780, $\mathrm{E}_{2}$, trans-resveratrol, 4-OHT or other compounds (see figure legends for details) for 4 days. Treatments were replenished after $48 \mathrm{~h}$. The absorbance of solubilized formazan product was measured at $570 \mathrm{~nm}$ (MTT) and $490 \mathrm{~nm}$ (Cell Titer 96) directly in each well. Within each experiment, each treatment was performed in quadruplicate and values were averaged. Values were compared with those in the wells treated with vehicle (EtOH) control which was set to $100 \%$. At least four separate experiments were performed for each cell line.

\section{RNA extraction and quantitative real time RT-PCR}

Cells were grown to $50-70 \%$ confluency in $100 \mathrm{~mm} \times 20 \mathrm{~mm}$ cell culture dishes in phenol-red-free media containing $10 \%$ DCC-FBS for $24 \mathrm{~h}$ prior to treatment with $\mathrm{EtOH}$ (vehicle control), $\mathrm{E}_{2}$ or other compounds indicated in the text for $6 \mathrm{~h}$. Cells were washed three times in PBS, and RNA was extracted using the TRIzol reagent (Invitrogen) according to the manufacturer's protocol followed by purification on RNeasy columns (Qiagen, Valencia, CA, USA). RNA quality was determined using the RNA 6000 Nano Assay kit on the Agilent 2100 Bioanalyzer (Wilmington, DE, USA). RNA concentration was determined by absorbance at $260 \mathrm{~nm}$. Total RNA was reverse-transcribed using random hexamers and the High Capacity cDNA archive kit (PE Applied Biosystems (ABI), Foster City, CA, USA). The QIAquick PCR purification kit (Qiagen) was used to purify cDNA.

ER $\alpha$, ER $\beta$ and $18 \mathrm{~S}$ rRNA Taqman primers and probes were purchased as Assays-on-Demand Gene Expression Products (ABI). Expression of genes was determined for each target gene in triplicate using $20 \mathrm{ng}$ of purified sample cDNA in each experiment and replicated twice for a total $n=3$. Each sample was normalized using 18S rRNA. The efficiency of each primer/probe set was evaluated by concentration optimization of primers, probes and input cDNA generating a standard curve with serial dilutions of untreated RNA. The efficiencies of real-time PCR of ER $\alpha, E R \beta$ and $18 \mathrm{~S}$ were $99.5,99.5$ and $97.9 \%$ with correlations of $0.986,0.968$ and 0.942 respectively. Real-time PCR was performed in the ABI PRISM 7700 SDS 2.1 using relative quantification with the following thermal cycler conditions: hold at $50^{\circ} \mathrm{C}$ for $2 \mathrm{~min}$ and $95^{\circ} \mathrm{C}$ for $10 \mathrm{~min}$, followed by 40 cycles of $95^{\circ} \mathrm{C}$ for $15 \mathrm{~s}$ and $60^{\circ} \mathrm{C}$ for $1 \mathrm{~min}$ in a $20 \mu \mathrm{l}$ reaction in 96-well plates. Each 96-well plate also included minus RT and reaction mix without cDNA as negative controls. Analysis and fold differences were determined using the comparative cycle threshold $\left(C_{\mathrm{T}}\right)$ method as described in ABI Technical Bulletin 2 (Bustin 2002, Ginzinger 2002). Fold change was calculated from the $\Delta \Delta C_{\mathrm{T}}$ values with the formula $2^{-\Delta \Delta C_{\mathrm{T}}}$ and is given as percentage relative expression compared with $\mathrm{MCF}-7$ cells.

\section{Preparation of whole-cell extracts (WCEs)}

Each cell line was grown in its corresponding culture medium supplemented with $10 \%$ DCC-FBS, $1 \%$ penicillin/streptomycin plus the indicated concentrations of chemicals for $24 \mathrm{~h}$ prior to harvest. When cell treatment experiments were performed, cells were grown in phenol-red-free media supplemented as above plus the treatment(s) indicated in the figure legends and text. WCEs were prepared in RIPA buffer (50 mM Tris- $\mathrm{HCl}, \mathrm{pH} 7.4 ; 1 \%$ Nonidet P-40; $0.25 \%$ 
Na-deoxycholate; $150 \mathrm{mM} \mathrm{NaCl} ; 1 \mathrm{mM}$ EDTA; $1 \mathrm{mM}$ phenylmethylsulfonyl fluoride (PMSF); aprotinin, leupeptin and pepstatin, each at $1 \mu \mathrm{g} / \mathrm{ml} ; 1 \mathrm{mM} \mathrm{Na}_{3} \mathrm{VO}_{4}$; $1 \mathrm{mM} \mathrm{NaF}$ ). Protein concentrations were determined using BioRad's DCC assay (Hercules, CA, USA).

\section{Specific $\left[{ }^{3} \mathrm{H}\right] \mathrm{E}_{2}$ binding assay}

Nuclear and cytoplasmic fractions (NE and CE) were prepared from each cell line using the NE-PER nuclear and cytoplasmic extraction reagents (Pierce, Rockford, IL, USA) according to the manufacturer's recommendations. Specific $\left[{ }^{3} \mathrm{H}\right] \mathrm{E}_{2}$ binding to baculovirusexpressed recombinant human $\mathrm{ER} \alpha(\mathrm{rhER} \alpha)$ and rhER $\beta$ (Kulakosky et al. 2002, Kulakosky \& Klinge 2003) or to the NE, CE and WCE from the lung cell lines was measured in the presence of 200-fold molar excess of 'cold' $E_{2}$ by adsorption to hydroxyapatite (HAP) as previously described (Kulakosky et al. 2002).

\section{Western blotting}

Identical amounts of whole-cell lysate extract (25$40 \mu \mathrm{g}$ protein) were separated on $10 \%$ SDS-PAGE gels and electroblotted on to polyvinylidene fluoride (PVDF) membranes (Pall Corporation, Pensacola, FL, USA). As positive and negative controls, known amounts (in fmoles from HAP assays) of baculovirus-expressed $\operatorname{rhER} \alpha$ and $\operatorname{rhER} \beta$, purchased from Panvera or produced in Sf21 cells (Kulakosky et al. 2002, Kulakosky \& Klinge 2003) were separated in parallel with WCE samples. The transfer was monitored by pre-stained molecular weight markers (Precision Standard, BioRad). Following transfer, membranes were blocked in 5\% milk Trisbuffered saline (TBS)-Tween then probed with antibodies: anti-ER $\alpha$ monoclonal antibody AER320 recognizes aa 495-595 (LabVision-Neomarkers, Fremont, CA, USA); anti-ER $\beta$ polyclonal antibody H-150 (Santa Cruz Biotechnology, Santa Cruz, CA, USA) recognizes aa $1-150$ of $h E R \beta$ and N-19 (Santa Cruz Biotechnology) also recognizes the $\mathrm{N}$-terminus of hER $\beta$; anti-progesterone receptor (PR) monoclonal antibody AB-8 recognizes the $\mathrm{N}$-terminal half of hPR (LabVision-Neomarkers). E-cadherin antibody (no. 4065) was purchased from Cell Signaling (Beverly, MA, USA). Blots were stripped and re-probed with anti- $\beta$-actin (Sigma) or $\alpha$-tubulin (LabVision-Neomarkers) to normalize for protein loading. The antibody to DRIP205 was kindly provided by Dr M Garabedian (Pineda Torra et al. 2004). Super Signal West Pico Chemiluminescent Substrate (Pierce) was used to detect protein bands. Resulting immunoblots were scanned into Adobe
Photoshop 7.0 using a Microtek ScanMaker III scanner (Carson, CA, USA). Un-Scan-It (Silk Scientific, Orem, UT, USA) was used to quantitate the integrated optical densities (IOD) for each band. The IOD for ER $\alpha, E R \beta, P R$, and E-cadherin were divided by concordant $\beta$-actin IOD in the same blot.

\section{Transient transfection assay}

For transient transfection, cells were plated in 24-well plates at a density of $1.5 \times 10^{4}$ cells/well in phenol-redfree OPTI-MEM I reduced serum medium (Gibco/ Invitrogen) supplemented with 10\% DCC-FBS, $1 \%$ penicillin/streptomycin. Transient transfection was performed using FuGene6 (Roche). Each well received $250 \mathrm{ng}$ of a pGL3-pro-luciferase reporter (Promega) containing two tandem copies of a consensus estrogen response element (ERE; i.e. EREc38 (Tyulmenkov et al. 2000)) and $5 \mathrm{ng}$ Renilla luciferase reporter (pRL-tk) from Promega. At $24 \mathrm{~h}$ after transfection, triplicate wells were treated with EtOH (vehicle control), $\mathrm{E}_{2}$, 4-OHT, DPN, PPT, ICI 182,780, resveratrol or other compounds as indicated in the figures. The cells were harvested $30 \mathrm{~h}$ post-treatment using Promega's Passive Lysis buffer. Luciferase and Renilla luciferase activities were determined using Promega's dual-luciferase assay in a Plate Chameleon luminometer (BioScan, Washington, DC, USA). Firefly luciferase was normalized by Renilla luciferase to correct for transfection efficiency. Fold induction was determined by dividing the averaged normalized values from each treatment by the EtOH value for each transfection condition within that experiment. Values were averaged from multiple experiments as indicated in the figure legends.

\section{Statistics}

Statistical analyses were performed using Student's $t$ test or one-way ANOVA followed by StudentNewman-Keuls or Dunnett's post-hoc tests using GraphPad Prism (San Diego, CA).

\section{Results}

$\mathrm{E}_{2}$ stimulates, and 4-OHT and ICI 182,780 inhibit, the proliferation of female lung adenocarcinoma cell lines. We examined the effect of $\mathrm{E}_{2}, 4-\mathrm{OHT}$, ICI 182,780 and R,R-THC (a selective ER $\alpha$ agonist/ER $\beta$ antagonist (Sun et al. 1999)) alone or in combination on the proliferation of lung adenocarcinoma cell lines from females (Fig. 1) and males (Fig. 2). Of the cell lines from females, H1395 showed the most stimulation by $E_{2}$ and $H 2073$ showed the least. The magnitude of 

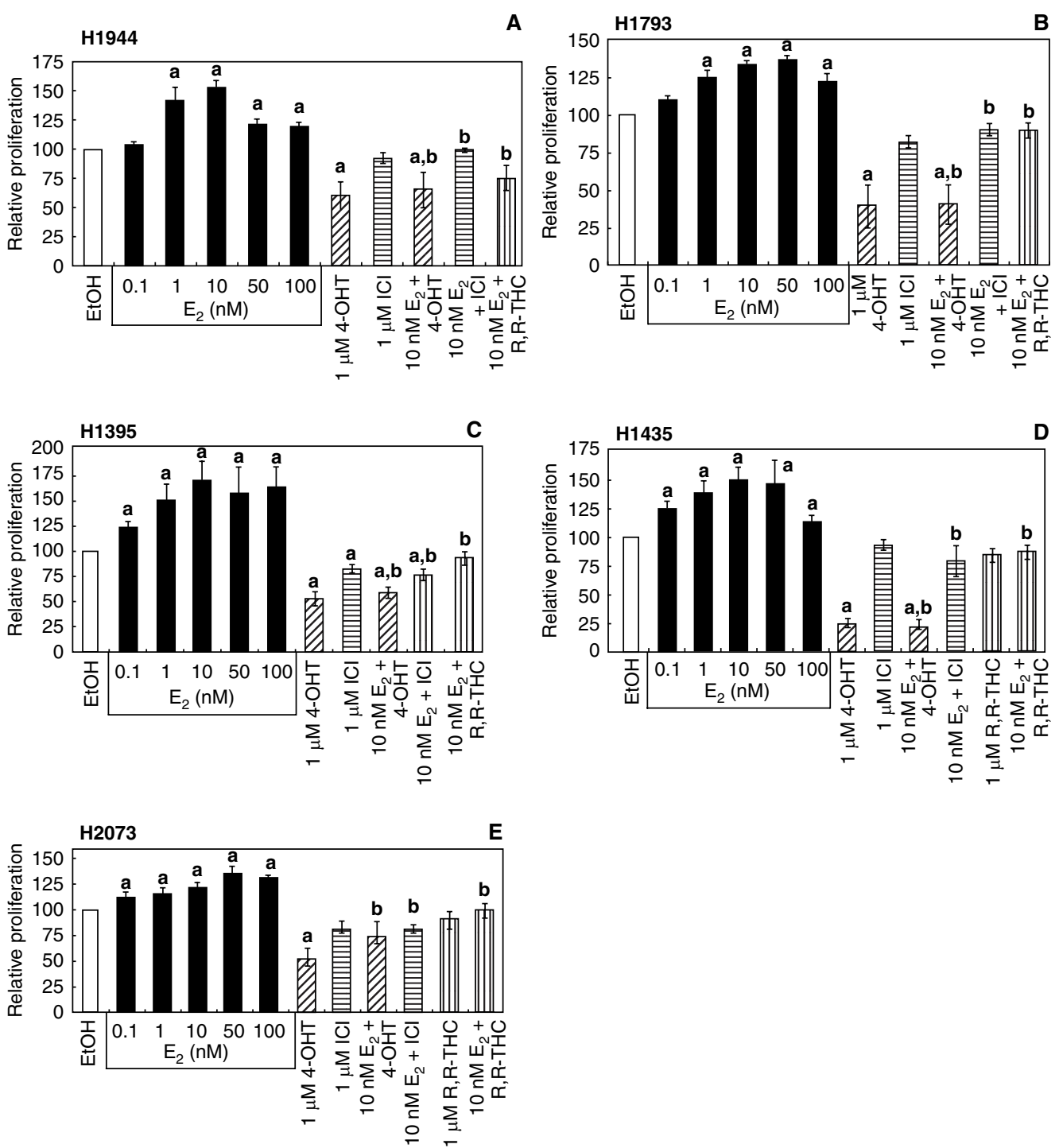

Figure $1 E_{2}$ stimulates and anti-estrogens inhibit the proliferation of lung adenocarcinoma cell lines from females. $\mathrm{H} 1944(\mathrm{~A})$, H1793 (B), H1395 (C), H1435 (D) and H2073 (E) lung adenocarcinoma cells, all from females, and MCF-7 human breast cancer cells $(F)$ were treated with the indicated concentrations of $E_{2}, 4-\mathrm{OHT}, \mathrm{ICI} 182,780$ and R,R-THC; or the indicated combinations thereof for 4 days with media (plus treatment) changed on day 2. Cell proliferation was measured by MTT assay. Each bar represents the mean \pm S.E.M. of at least six independent experiments. a, significantly different from control $(\mathrm{EtOH}) \mathrm{values}$;

$\mathrm{b}$, significantly different from the $10 \mathrm{nM} \mathrm{E}_{2}$ alone value, $P<0.05$.

$\mathrm{E}_{2}$-induced proliferation is consistent with that seen in MCF-7 breast cancer cells (Fig. 1F) and reported for the $201 \mathrm{~T}$ adenocarcinoma cell line (Hershberger et al. 2005). $\mathrm{E}_{2}$ stimulation was blocked by 4-OHT - which is an active metabolite of the drug tamoxifen, used clinically to block ER action in breast cancer (Jordan \& Pappas 2003) - and ICI 182,780 (Faslodex), a pure steroidal ER antagonist. 4-OHT inhibited proliferation in all cell lines from females. The inhibition of $E_{2}-$ induced proliferation by R,R-THC, an ER $\beta$-selective
antagonist/ER $\alpha$ agonist (Sun et al. 1999), was similar to that with ICI 182,780, but less than 4-OHT, suggesting the possibility that ER $\beta$ may have a role in cell replication.

In contrast to the results in the lung adenocarcinoma cell lines from females, $\mathrm{E}_{2}$ had no effect on the proliferation of NF1604 (Fig. 2A) or any of the adenocarcinoma cells from males (Fig. 2B-E). The lack of $\mathrm{E}_{2}$-induced proliferation of $\mathrm{H} 23$ cells contradicts the stimulatory effect of $E_{2}$ reported previously 

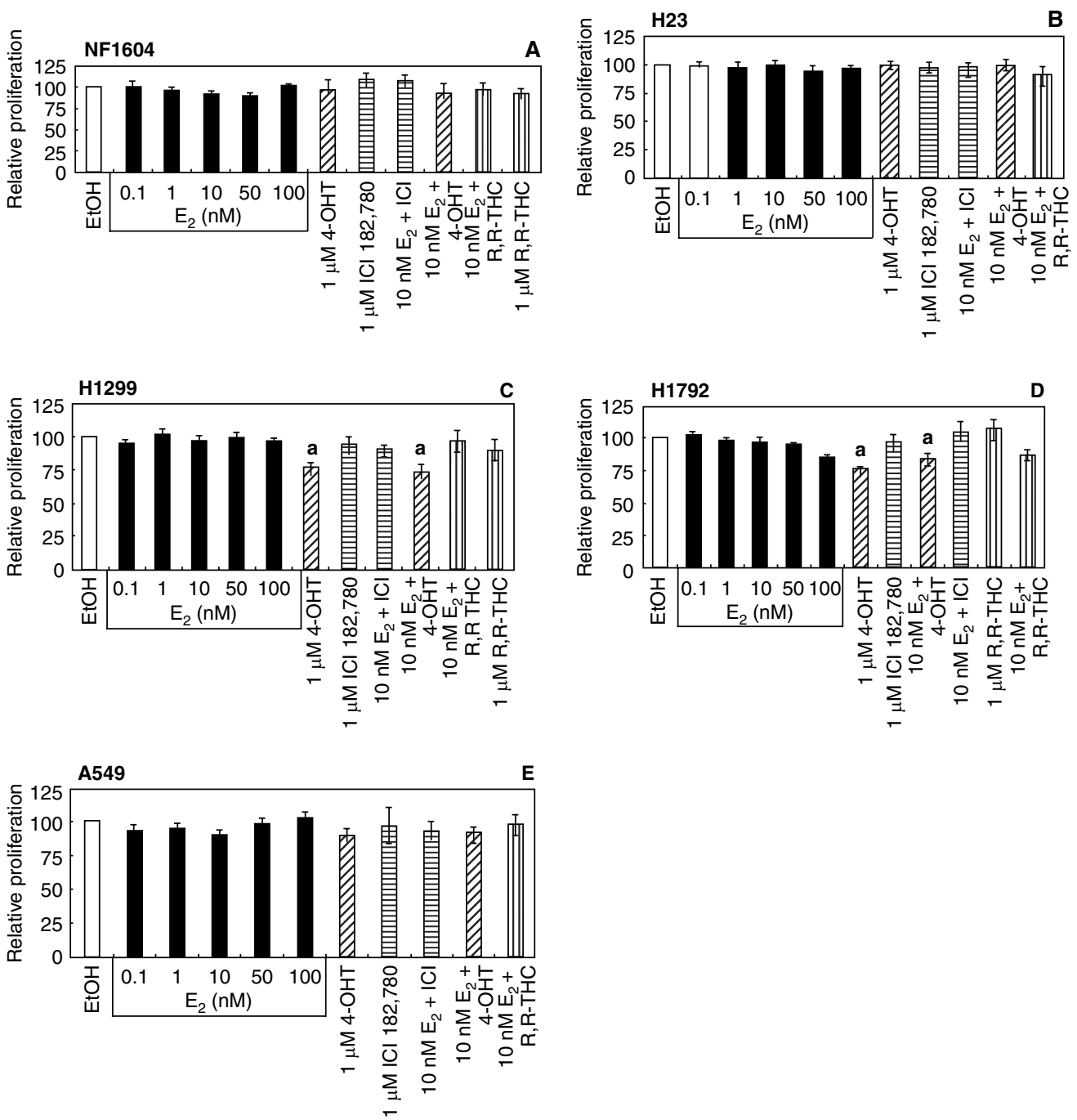

Figure 2 ER ligands do not affect the proliferation of NF1604 normal lung fibroblasts or adenocarcinoma cell lines from males. NF1604 (A), H23 (B), H1299 (C), H1792 (D) and A549 (E) lung adenocarcinoma cells, all from males, were treated with the indicated concentrations of $\mathrm{E}_{2}, 4-\mathrm{OHT}, \mathrm{ICl} 182,780$ and $\mathrm{R}, \mathrm{R}-\mathrm{THC}$; or the indicated combinations thereof for 4 days as described in the Materials and methods section and Fig. 1. Cell proliferation was measured by MTT assay as described in the Materials and methods. Values are expressed as relative to $\mathrm{EtOH}$ control. Each bar represents the mean \pm S.E.M. of at least six independent experiments; a, significantly different from control (EtOH) values, $P<0.05$.

(Stabile et al. 2002). The reason for this discrepancy may result from the 24-h serum-free incubation of the $\mathrm{H} 23$ cells prior to $\mathrm{E}_{2}$ treatment in the previous report (Stabile et al. 2002). In contrast, we maintained all cell lines in $10 \%$ DCC-FBS for $24 \mathrm{~h}$ prior to hormone treatment. Thus, the hormone/ligand effects we measured may be reduced in magnitude compared with serum-deprived cells.

ICI 182,780 (Faslodex) had no effect on the proliferation of lung adenocarcinoma cell lines from males. 4-OHT inhibited the proliferation of H1299 and $\mathrm{H} 1792$ cells by $\sim 20 \%$ (Fig. 2C and D). In the case of $\mathrm{H} 1299$, the combination of $\mathrm{E}_{2}$ and 4-OHT also inhibited proliferation by approximately $25 \%$. Notably, 4-OHT alone or combined with $\mathrm{E}_{2}$ had a greater inhibitory effect on the proliferation of adenocarcinoma cells from females (Fig. 1) than males; i.e. reducing proliferation by $50-75 \%$ versus $20 \%$ respectively. R, R-THC did not affect the proliferation of any of the cell lines from males, whether alone or in combination with $\mathrm{E}_{2}$. We conclude that lung adenocarcinoma cell lines from females are more responsive to $\mathrm{E}_{2}$, 4-OHT, ICI 182,780 and R,R-THC compared with cell lines from males. 

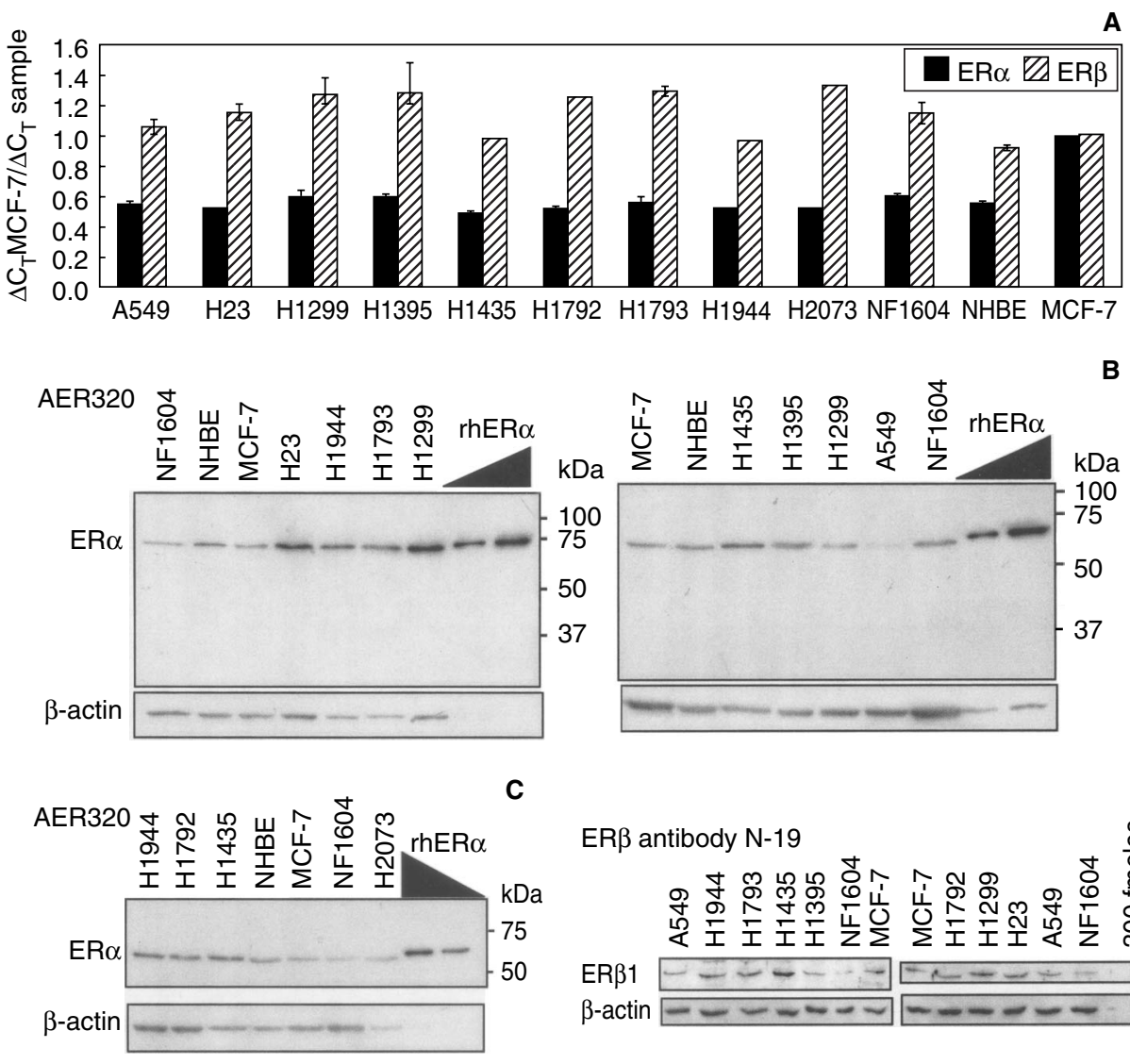

ER $\beta$ antibody $\mathrm{H} 150$

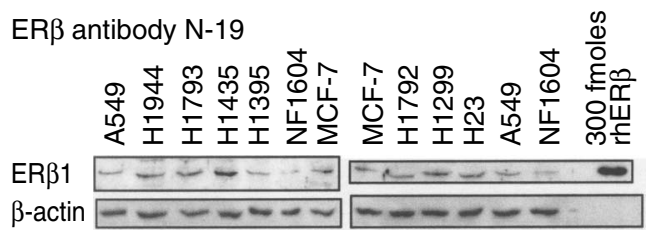

E
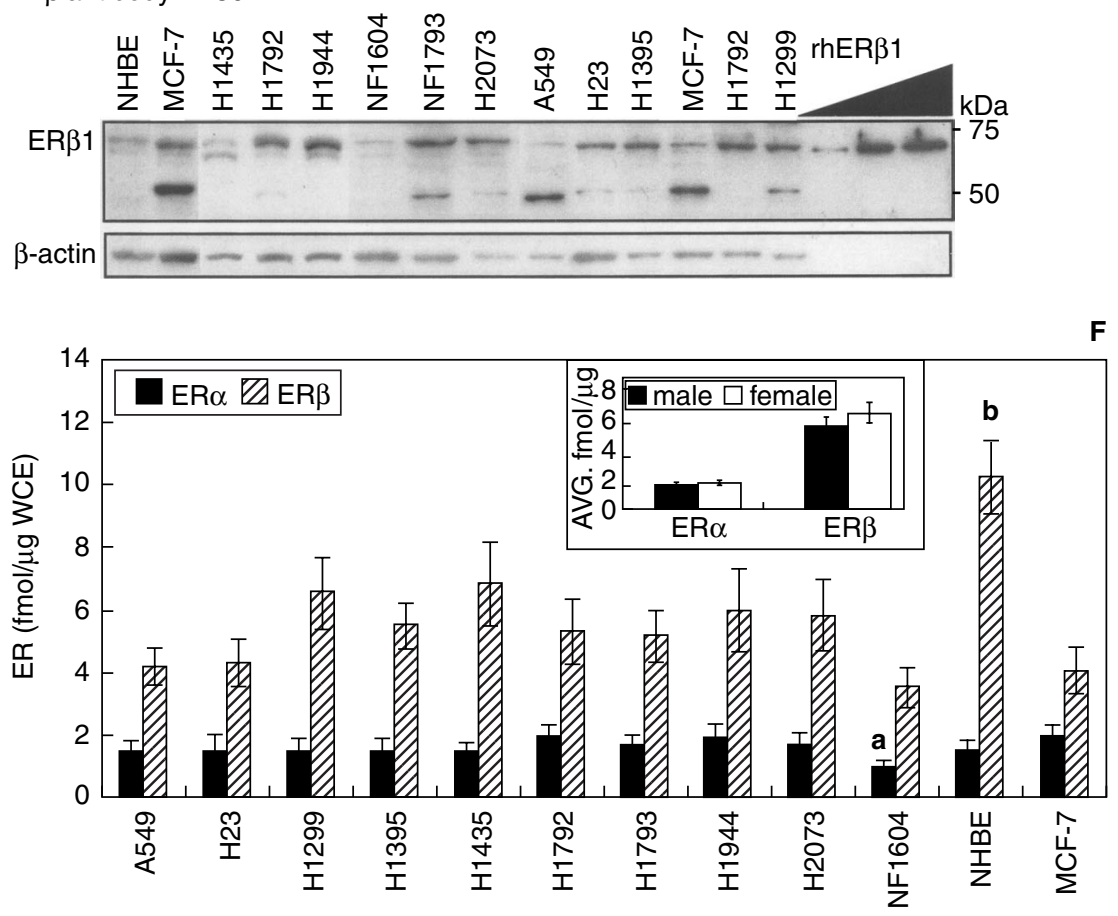
G
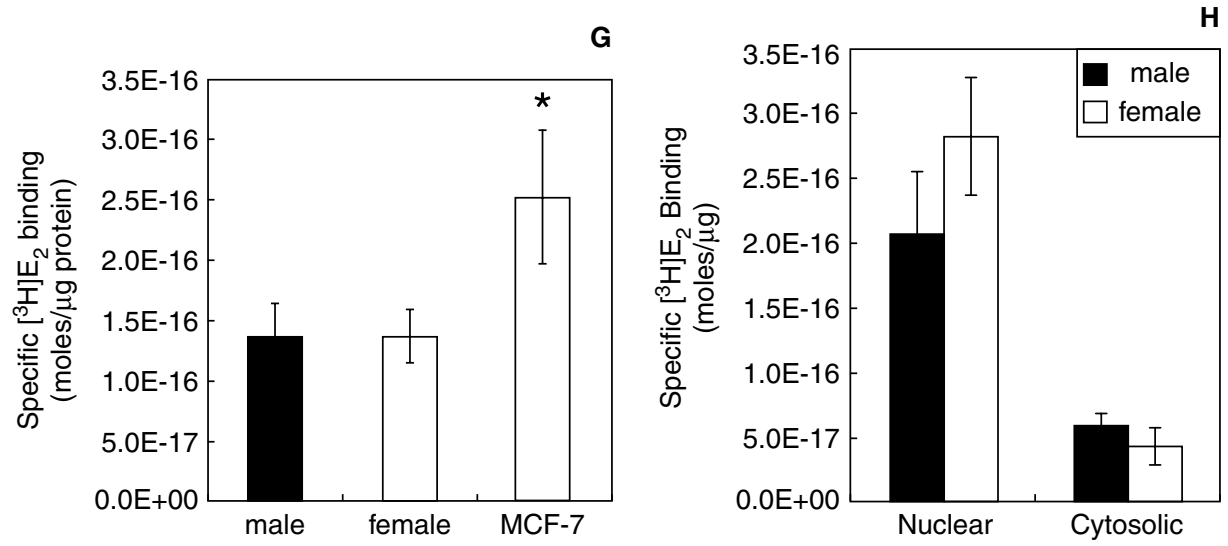

Figure $3 \mathrm{ER} \alpha$ and ER $\beta$ are expressed in lung adenocarcinoma cells. (A) Quantitation of mRNA expression of ER $\alpha$ and ER $\beta$ by real-time RT-PCR was performed as described in the Materials and methods section. Values are the means \pm S.E.M. of quadruplicate determinations and are normalized by ER $\alpha$ and ER $\beta$ expression in MCF-7 cells. (B and C) Western blots for ER $\alpha$ using ER $\alpha$ antibody AER320. ( $D$ and E) Western blots for ER $\beta$ using ER $\beta$ antibodies $\mathrm{N}-19$ and $\mathrm{H}-150$ respectively. The blots were stripped and re-probed for $\beta$-actin expression for normalization. Known amounts of rhER $\alpha$ ( 25 and $62 \mathrm{fmol})$ and rhER $\beta$ $(150,225$ and $300 \mathrm{fmol})$, determined by HAP assay as described in the Materials and methods, were separated in parallel with the lung sample WCE. Estimation of $\mathrm{ER} \alpha$ and $\mathrm{ER} \beta 1$ concentrations was performed as described in the Materials and methods. (F) The expression of ER $\alpha$ and ER $\beta 1$ from different WCE preparations was quantitated by Western blotting. Each bar represents the mean \pm S.E.M. of at least five independent experiments. The inset shows the mean \pm S.E.M. for values from the adenocarcinoma cell lines from males and females; $a$, significantly different from ER $\alpha$ expression in $\mathrm{MCF}-7, P<0.001 ; \mathrm{b}$, significantly different from ER $\beta 1$ expression in any other cell line, $P<0.001$; as determined by one-way ANOVA followed by Student-Newman-Keuls multiple comparison test. Specific $\left[{ }^{3} \mathrm{H}\right] \mathrm{E}_{2}$ binding to WCE $(\mathrm{G})$ and CEs and NEs $(\mathrm{H})$ was measured by HAP assay as described in the Materials and methods. Values are the means \pm S.E.M. of triplicate determinations.

*Statistically different from values for lung adenocarcinoma cell lines from male and female, $P<0.01$; one-way ANOVA followed by Student-Newman-Keuls multiple comparison test.

\section{Expression of ER $\alpha$ and ER $\beta$ mRNA and protein in lung adenocarcinoma cells}

One possible explanation for the lack of estrogen responsiveness in the lung adenocarcinoma cells from males is that they do not express ER or express ER at reduced levels compared with the cells from females. Of the nine adenocarcinoma cell lines used in this study, the ER status has been reported in A549, H23 and H1435 (Table 1). It is noteworthy that contradictory findings were reported (Table 1).

Quantitative real-time RT-PCR was used to determine ER $\alpha$ and ER $\beta$ mRNA expression in NHBE, NF1604 and the lung adenocarcinoma cell lines (Fig. 3A). Fold differences in gene expression were determined by the comparative $C_{\mathrm{T}}$ method using $18 \mathrm{~S}$ rRNA as the endogenous control. MCF-7 cells were used as the calibrator and expressed more ER $\alpha$ mRNA than NHBE, NF1604 or any of the lung adenocarcinoma cell lines. ER $\beta$ mRNA expression was higher than $E R \alpha$ expression in all the lung cell lines. There was no difference in ER $\alpha$ mRNA expression between NHBE, NF1604 and the lung adenocarcinoma cell lines. H23, H1299, H1395, H1792,
H1793, H2073 and NF1604 expressed higher levels of ER $\beta$ mRNA than MCF-7 cells.

To determine ER $\alpha$ and $E R \beta$ protein expression, known concentrations, as assayed by $\left[{ }^{3} \mathrm{H}\right] \mathrm{E}_{2}$ binding (Kulakosky et al. 2002), of baculovirus-expressed $\operatorname{rhER} \alpha$ and $\operatorname{rhER} \beta$ protein were separated in parallel with the WCEs of the lung adenocarcinoma cell lines and used as calibrators to estimate ER $\alpha$ and ER $\beta$ expression levels by Western blot (Fig. 3B-E). All cell lines expressed full-length $\mathrm{ER} \alpha$ and no shorter $\mathrm{ER} \alpha$ products were detected (Fig. 3B and C). These data indicate that intact $\mathrm{ER} \alpha$ is expressed in the adenocarcinoma cell lines. Our data differ from a report that MCF-7, H23 and A549 expressed ER $\alpha$ as 80 and $54 \mathrm{kDa}$ bands, but that only MCF-7 expressed $67 \mathrm{kDa}$ $\mathrm{ER} \alpha$ (Stabile et al. 2002). ER $\alpha$ expression in NHBE and all adenocarcinoma cell lines was similar to MCF-7 cells whereas NF1604 was lower (Fig. 3F).

As antibodies have a history of showing crossreactivity with $\mathrm{ER} \alpha$, we used two different antibodies to examine ER $\beta$ expression. We have demonstrated the specificity of the AER320 ER $\alpha$ and H150 ER $\beta$ antibodies for their respective ER subtype (Klinge et al. 2005). The N-19 antibody only recognized the 

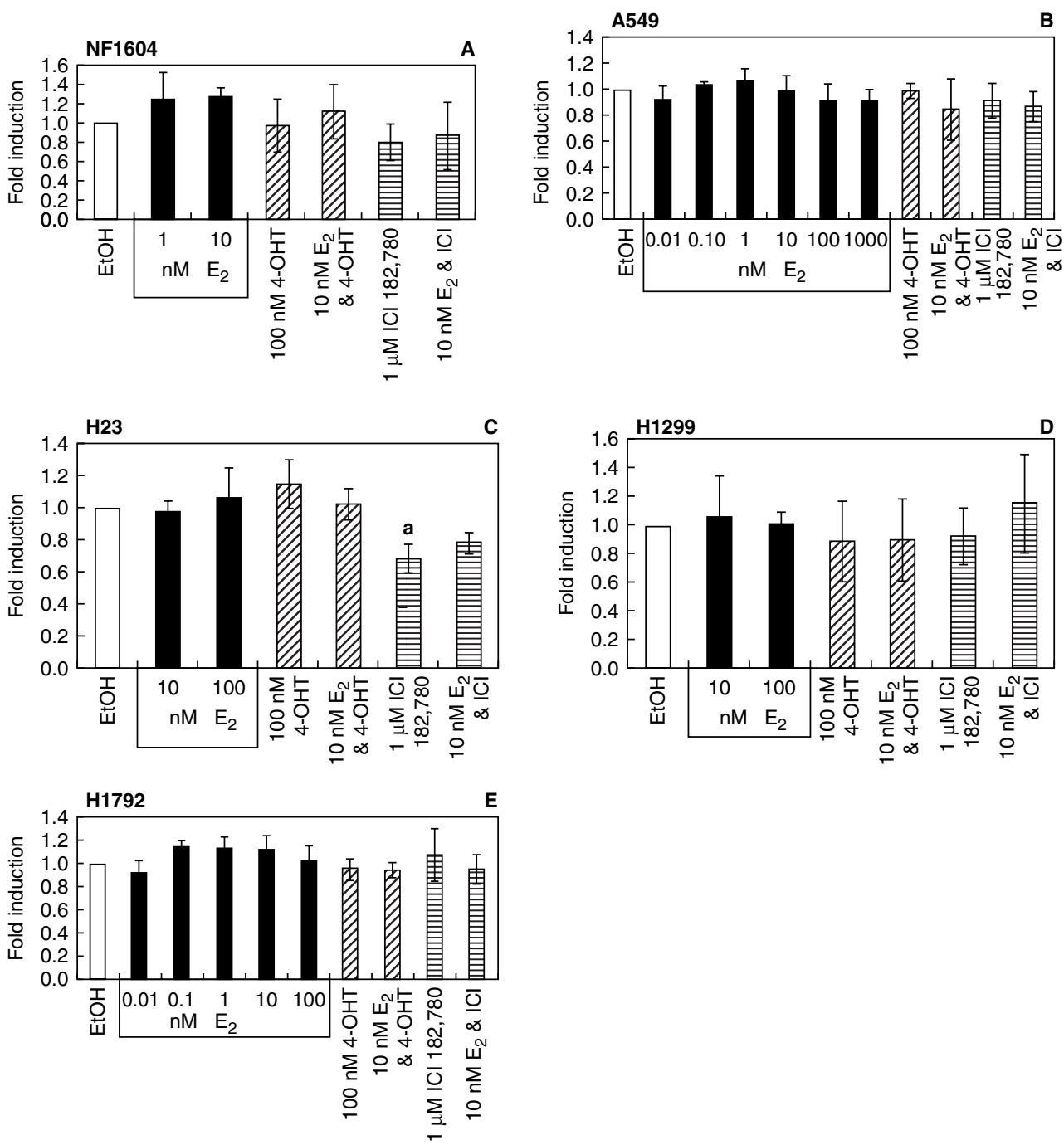

Figure 4 Lack of estrogen responsiveness of NF1604 and male lung adenocarcinoma cells in transient transfection assay. NF1604 (A), A549 (B), H23 (C), H1299 (D) and H1792 (E) male adenocarcinoma cells were transiently transfected with an ERE-luciferase reporter as described in the Materials and methods section. The cells were treated with the indicated

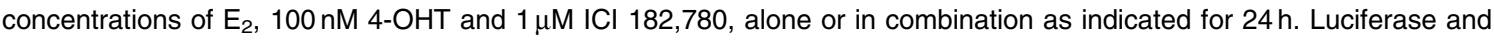
Renilla luciferase were assayed as described in the Materials and methods. Luciferase values were normalized by Renilla luciferase values and the relative light unit (RLU) value for $\mathrm{EtOH}$ (vehicle control) was set to 1. Values are the means \pm S.E.M. of three separate transient transfection assays; a, significantly different from $\mathrm{EtOH}$ control $(P<0.05$, Student's $t$ test).

ER $\beta 160 \mathrm{kDa}$ band (Fig. 3D), i.e. the 'long' isoform, and not the ER $\beta 1$ s 'short' isoform of ER $\beta$ (Scobie et al. 2002). Western blots using the H150 ER $\beta$ antibody indicated that most cells express the ER $\beta 1$ and ER $\beta 1 \mathrm{~s}$ isoforms as $61-64$ and $50-53 \mathrm{kDa}$ sizes respectively (Fig. 3E). A summary of the estimated $E R \alpha$ and ER $\beta$ expression in the cells based on Western blotting is presented in Fig. 3F. ER $\beta$ expression was greater than $\mathrm{ER} \alpha$ expression in all lung adenocarcinoma cell lines, and in NHBE and NF1604 cells than in MCF-7 cells. NHBE cells showed higher ER $\beta$ expression than NF1604, MCF-7 or any of the lung adenocarcinoma cell lines. Others have reported ER $\beta 1$ migrating as $62-64 \mathrm{kDa}$ in human tissues (Choi et al. 2001 ) and ER $\beta$ from mouse lung was $65 \mathrm{kDa}$ (Patrone et al. 2003). As ER $\beta$ splice variants $E R \beta 2 / c x L$ and $\mathrm{ER} \beta 2 / \mathrm{cxS}$ are expressed in human tissues as $55-51 \mathrm{kDa}$ proteins, it is possible that the lower ER $\beta$ band detected in the Western blots shown here may represent more than one isoform of ER $\beta$. Further testing will be 

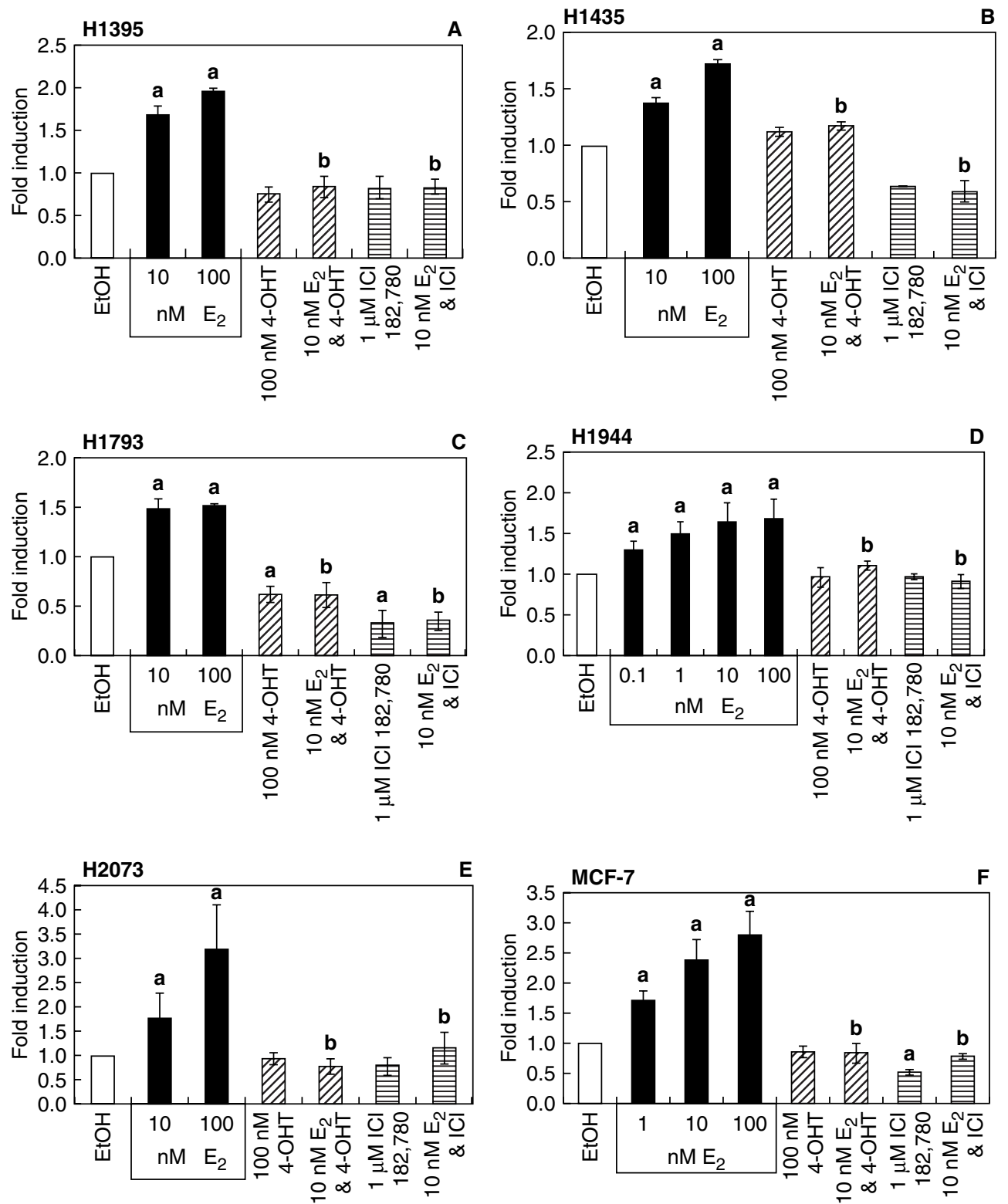

Figure $5 \mathrm{E}_{2}$ stimulates endogenous ER transcriptional activity in female human lung adenocarcinoma cells as determined by transient transfection assay. H1395 (A), H1435 (B), H1793 (C), H1944 (D) and H2073 (E) female adenocarcinoma cells and MCF-7 breast cancer cells (F) were transiently transfected with an ERE-luciferase reporter; they were then treated, harvested and assayed as described in the Materials and methods section, and Fig. 4. Note that these cells were not transfected with ER. a, Significantly different from EtOH control; b, significantly different from the $10 \mathrm{nM} \mathrm{E}_{2}$ alone value $(P<0.05$, Student's $t$ test).

required to examine this possibility. There was no correlation between the expression of the shorter ER $\beta$ protein and estrogen responsiveness or gender from which the cells were obtained. These data indicate that it is unlikely that over-expression of the dominant negative ER $\beta 2 / \mathrm{cx}$ isoform accounts for differences in estrogen responsiveness between cells.

\section{$\left[{ }^{3} \mathrm{H}\right] \mathrm{E}_{2}$ binding to endogenous $E R$ in lung adenocarcinoma cells}

Another explanation for the lack of $E_{2}$ response in the adenocarcinoma cells from males is that the expressed ER is non-functional. One functional measure of ER expression is specific $\left[{ }^{3} \mathrm{H}\right] \mathrm{E}_{2}$ binding. 


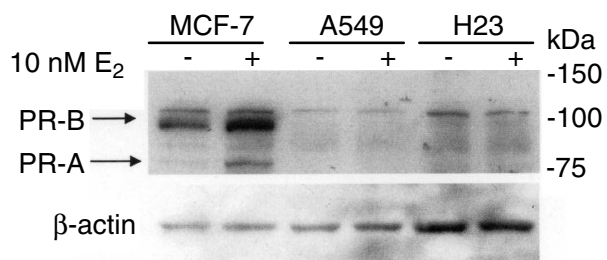

A
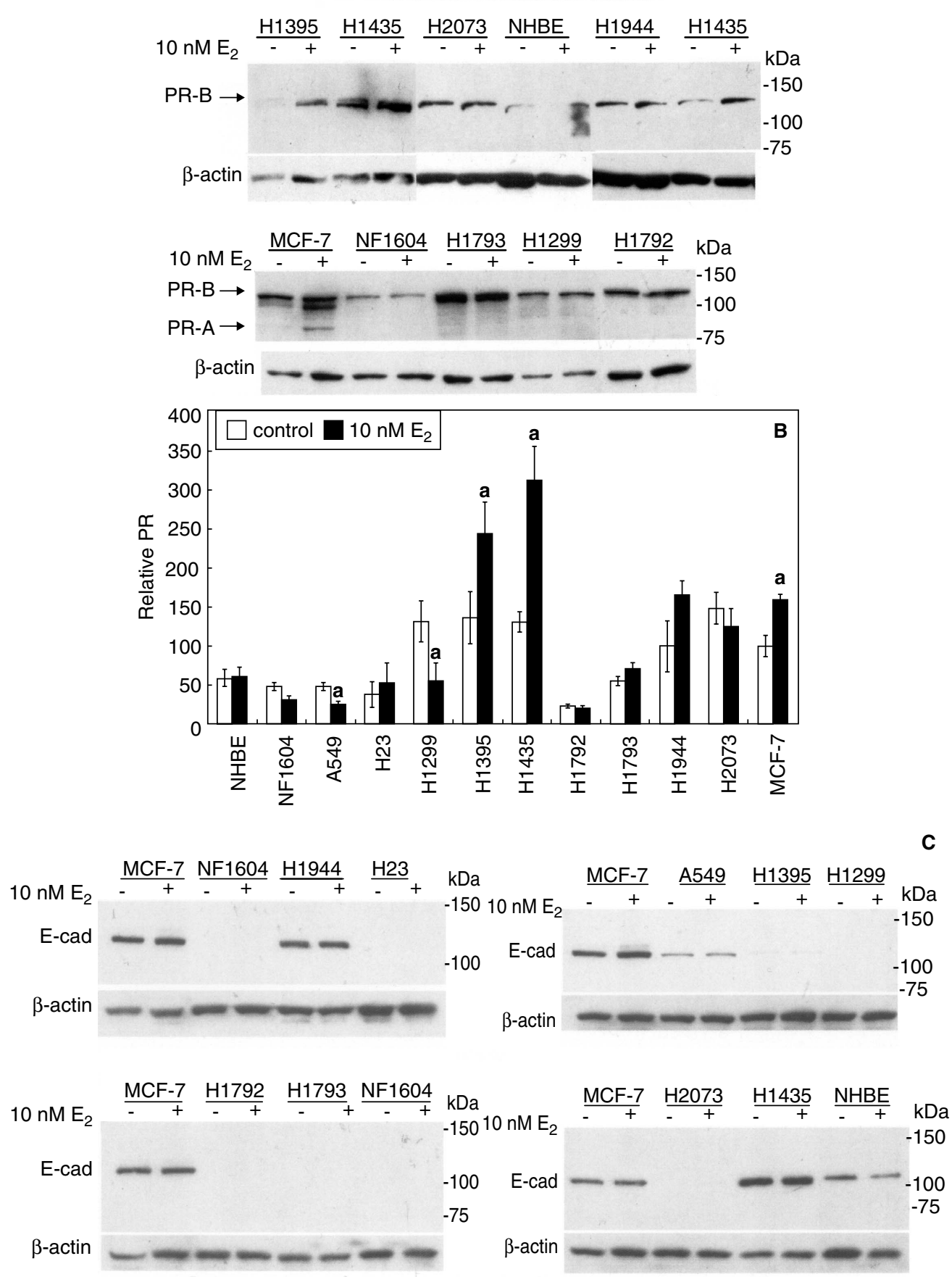


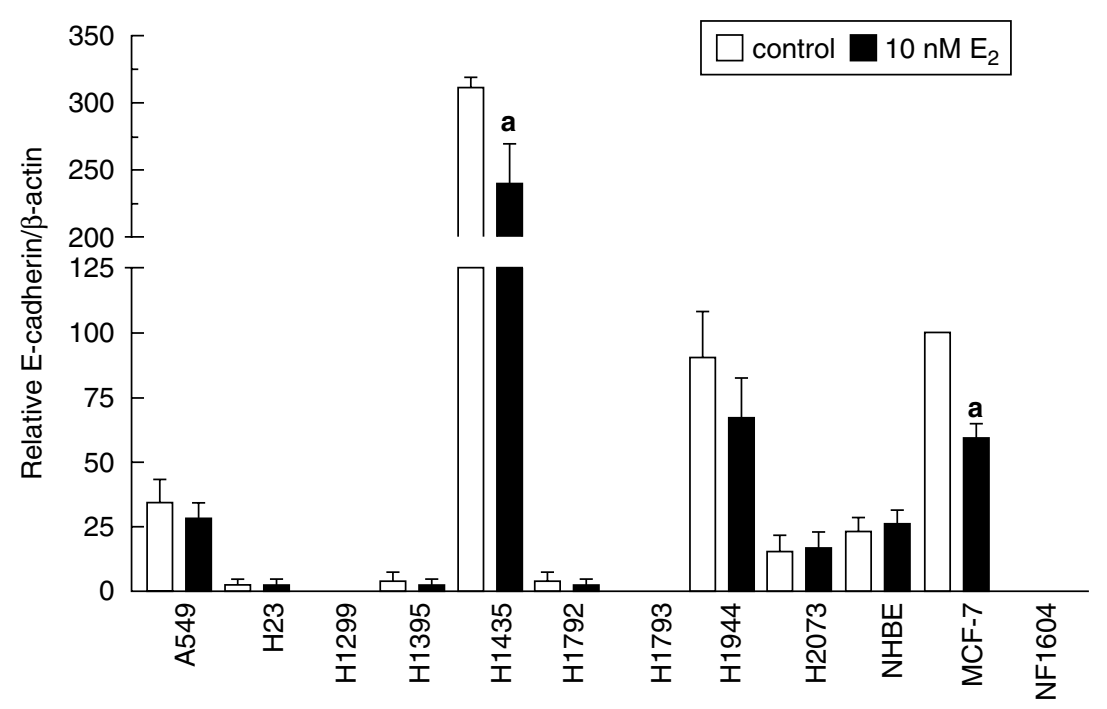

Figure $6 \mathrm{PR}$ is a marker of estrogen responsiveness in some of the lung adenocarcinoma cell lines from females and $\mathrm{E}$-cadherin is not a marker of estrogen response. Cells were treated with $\mathrm{EtOH}$ (vehicle) or $10 \mathrm{nM} \mathrm{E}_{2}$ for $24 \mathrm{~h}$. WCEs (35 $\left.\mu \mathrm{g}\right)$ were separated on $10 \%$ SDS-PAGE gels, transferred to PVDF membranes and immunoblotted for PR (A). PR-B is $116 \mathrm{kDa}$ and PR-A is $81 \mathrm{kDa}$. Membranes were stripped and re-probed for $\beta$-actin as a loading control. (B) Mean \pm S.E.M. ( $n=3-5)$ of the total PR (PR-B + PR-A) normalized by $\beta$-actin and with EtOH-treated MCF-7 PR expression set to 100\%; a, significantly different from $\mathrm{EtOH}$ control $(P<0.01)$. (C) Indicated cell lines were treated with $\mathrm{EtOH}$ (vehicle) or $10 \mathrm{nM} \mathrm{E}_{2}$ for $24 \mathrm{~h}$. WCEs $(35 \mu \mathrm{g})$ were separated on $12 \%$ SDS-PAGE gels, transferred to PVDF membranes and immunoblotted for E-cadherin. Molecular weight markers run in parallel in each gel (indicated in $\mathrm{kDa}$ ). Membranes were stripped and re-probed for $\beta$-actin. (D) Normalized E-cadherin expression relative to EtOH-treated MCF-7 cells that were set to $100 \%$. Values are the means \pm S.E.M. of three to six separate experiments; a, significantly different from EtOH control $(P<0.05)$.

Lung adenocarcinoma cell lines expressed 0.11 $0.16 \mathrm{fmol} \mathrm{ER} / \mu \mathrm{g}$ WCE protein, as measured by specific $\left[{ }^{3} \mathrm{H}\right] \mathrm{E}_{2}$ binding, and no statistical difference was detected between cell lines from males or females (Fig. 3G). $\left[{ }^{3} \mathrm{H}\right] \mathrm{E}_{2}$ binding in the lung samples was significantly lower than in MCF-7 cells. Since a possible explanation for the lack of $\mathrm{E}_{2}$ response in lung adenocarcinoma cells from males is that ER is excluded from the cell nucleus, we prepared NEs and CEs and measured $\left[{ }^{3} \mathrm{H}\right] \mathrm{E}_{2}$ binding to each fraction (Fig. $3 \mathrm{H}$ ). $\left[{ }^{3} \mathrm{H}\right] \mathrm{E}_{2}$ binding was higher in NEs than in CEs, but no difference was detected between samples from females or males.

\section{Transcriptional activity of endogenous ER in lung adenocarcinoma cells}

A second function of $E R$, in addition to $E_{2}$ binding, is to activate gene transcription. Most responses to $\mathrm{E}_{2}$ are mediated by the genomic ER pathway in which $\mathrm{E}_{2}$ stimulates or inhibits the transcription of target genes (Klinge 2000). To compare the transcriptional activity of endogenous ER in the adenocarcinoma cell lines, we performed transient transfection assays using a luciferase reporter driven by two tandem copies of an ERE (Klinge et al. 2004). $\mathrm{E}_{2}$ did not increase EREdriven luciferase activity in NF1604 cells (Fig. 4A) or in A549, H23, H1299 or H1792 cells from males (Fig. 4B-E). Thus, similar to results seen in the proliferation studies, the adenocarcinoma cell lines from males were non-responsive to $E_{2}$ in these transient transfection assays. ICI 182,780 suppressed basal transcription in $\mathrm{H} 23$, but not in any other cell line from males. Since ICI 182,780 targets ER $\alpha$ to the 26S proteasome for degradation (Marsaud et al. 2003), these results suggest a possible role for ER $\alpha$ in basal transcription of the transfected ERE-luciferase reporter in $\mathrm{H} 23$ cells.

In contrast, $\mathrm{E}_{2}$ stimulated ERE-driven luciferase activity in the adenocarcinoma cell lines from females (Fig. 5) and this stimulation was inhibited by concomitant treatment with 4-OHT or ICI 182,780, indicating that the effect was ER mediated. Further, these results are concordant with results from the MTT assays indicating $\mathrm{E}_{2}$ responsiveness in lung adenocarcinoma cell lines from females but not males, despite equivalent $\mathrm{ER} \alpha$ and $\mathrm{ER} \beta$ protein expression and specific $\left[{ }^{3} \mathrm{H}\right] \mathrm{E}_{2}$ binding activity. 4-OHT and ICI 
182,780 suppressed basal transcription in H1793 cells indicating that, as reported by others, 4-OHT-occupied ER can actively suppress transcription (Barsalou et al. 1998, Zhang et al. 1998, Planas-Silva et al. 2001, Thomas et al. 2003).

PR may be a marker of estrogen responsiveness in some lung adenocarcinoma cells from females. PR is a well-established marker of estrogen responsiveness in breast cancer (McGuire et al. 1986). Reports on PR expression in NSCLC are mixed. Some paraffin-embedded tumors showed PR expression by immunohistochemical staining (Kaiser et al. 1996, Su et al. 1996), but other studies reported no PR expression (Di Nunno et al. 2000, Radzikowska et al. 2002). Although some studies found no correlation between ER $\alpha$ and PR immunoreactivity in NSCLC (Kaiser et al. 1996, Su et al. 1996), one study reported higher PR in lung adenocarcinoma tumors from female patients compared with SCLC and adenocarcinomas from male patients (Kaiser et al. 1996). To determine if $E_{2}$ stimulated PR expression in lung adenocarcinoma cell lines, cells were grown in DCC-FBS for $24 \mathrm{~h}$ and then treated for $24 \mathrm{~h}$ with $10 \mathrm{nM} \mathrm{E} \mathrm{E}_{2}$. All the lung cell lines expressed PR-B (Fig. 6A). The positive control MCF-7 cells expressed predominately $\mathrm{PR}-\mathrm{B}$ and $\mathrm{E}_{2}$ increased $\mathrm{PR}$ protein expression by $\sim 50 \%$ (Fig. $6 \mathrm{~B}$ ). Interestingly, $\mathrm{E}_{2}$ increased PR expression in H1395 and H1435 cells from females. Thus, two out of five of the cell lines from females showed $E_{2}$-stimulated $P R$ expression. $E_{2}$ decreased PR expression in A549 and H1299 cells from males. We conclude that PR may be an endogenous marker for $E_{2}$ responsiveness in some lung adenocarcinomas from females.

\section{E-cadherin expression is not stimulated by $E_{2}$ in lung adenocarcinoma cell lines}

E-cadherin is a calcium-dependent cell-cell adhesion molecule that is a marker for epithelial differentiation and is considered to be a tumor suppressor gene (Merot et al. 2004). The mRNA and protein levels of E-cadherin were recently reported to be stimulated by $E_{2}$ in $201 \mathrm{~T}$ adenocarcinoma and in $273 \mathrm{~T}$ squamous cell carcinoma lung cancer cell lines (Hershberger et al. 2005). Thus, we investigated whether $\mathrm{E}_{2}$ stimulates E-cadherin expression in the cell lines used in this study (Fig. 6C). As anticipated, E-cadherin was not expressed in NF1604 cells. $E_{2}$ decreased E-cadherin expression in MCF-7 cells (Fig. 6D). This agrees with previous reports on $\mathrm{E}_{2}-\mathrm{ER}$-mediated inhibition of E-cadherin expression in MCF-7 and other breast cancer cell lines (Oesterreich et al. 2003).
E-cadherin was expressed in NHBE cells and its expression was not altered by $\mathrm{E}_{2}$. Not all the adenocarcinoma cell lines expressed E-cadherin and in the cell lines expressing E-cadherin - i.e. A549, H1944, $\mathrm{H} 1395, \mathrm{H} 1435, \mathrm{H} 1944$ and $\mathrm{H} 2073-\mathrm{E}_{2}$ either had no effect or decreased E-cadherin expression (Fig. 6D). These results contradict the conclusion that E-cadherin is an $\mathrm{E}_{2}$-up-regulated target gene in NSCLC cells (Hershberger et al. 2005); however, because different cell lines were used, no generalizations can be made. We suggest that the cell lines expressing little or no E-cadherin represent more aggressive lung adenocarcinoma cell lines - i.e. H23, H1299, H1792 and H1793 - since functional loss of E-cadherin is associated with an epithelial-to-mesenchymal transition in carcinogenesis that results in invasion (Kumar \& Hung 2005). Indeed, H1299 is from lymph node metastases, and H1792 from a pleural effusion from a patient with stage 4 disease; H2073 is from a patient with stage $3 \mathrm{~A}$ disease, according to the ATCC web site (http://www.atcc.org/).

\section{PBP/TRAP220/DRIP205 expression is higher in lung adenocarcinoma cell lines than NHBE cells}

A difference in ER expression does not appear to be responsible for the proliferative activity of $E_{2}$ and the anti-proliferative activity of 4-OHT and ICI 182,780 in lung adenocarcinoma cells from females versus males. Thus, we hypothesized that the expression or activity of some critical component(s) of the ER signaling pathways, e.g. coactivators and/or corepressors, may be different between lung adenocarcinomas from male and female patients, a possibility that we are currently investigating. Previous studies showed that ER $\alpha$ interacts directly with coactivator peroxisome proliferator-activated receptor (PPAR)binding protein $(\mathrm{PBP})$ /thyroid receptor-associated protein (TRAP)220/Vitamin D receptor interacting protein (DRIP)205/Mediator 1 (MED1) and that DRIP205 is recruited to estrogen target genes in an $\mathrm{E}_{2}$-dependent, cyclic manner in MCF-7 breast cancer cells (Burakov et al. 2000, 2002, Kang et al. 2002). Further, since $\mathrm{PBP} / \mathrm{TRAP} 220 / \mathrm{DRIP} 205$ is an essential mediator of ER-mediated transcription at estrogen target genes (Zhang et al. 2005), we examined the expression of DRIP205 protein in lung adenocarcinoma cells from females versus males (Fig. 7). DRIP205 expression was higher in the lung adenocarcinoma cell lines and in MCF-7 cells compared with NHBE or NF1604 cells. The nature of the identity of the lower molecular weight bands recognized by the DRIP205 antibody in 
A

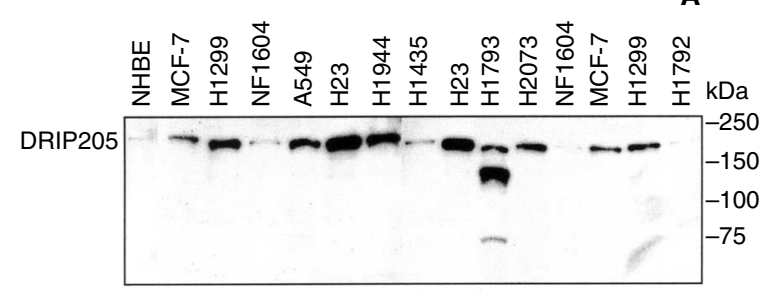

$\alpha$-tubulin

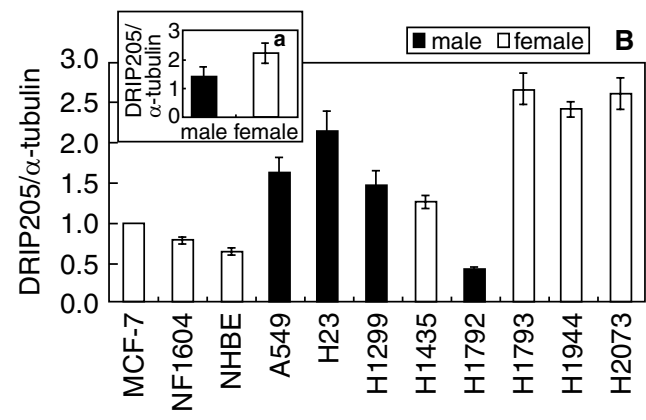

Figure 7 Coactivator DRIP205 is expressed in lung adenocarcinoma cell lines. Western blots for PBP/TRAP220/DRIP205 were performed using a monoclonal antibody to DRIP205 (Pineda Torra et al. 2004). The blots were stripped and re-probed for $\alpha$-tubulin for normalization. Values of pixel densities were normalized by MCF-7 cells, which were set to 1 , and are the average of two blots \pm S.D. The inset shows the mean \pm S.E.M. for values from the adenocarcinoma cell lines from males and females; a, significantly different from the average value from cell lines from males $(P<0.05)$.

H1793 is unknown, but only the full-length DRIP205 value was included in the calculations (Fig. 7B). Although, H1435 cells (female) showed expression similar to that of A549 (male) and H1299 (male), the average DRIP205 expression in lung adenocarcinoma cell lines from females was significantly higher than that in the cell lines from males.

\section{Discussion}

The mechanisms accounting for the observed higher incidence of lung adenocarcinoma in females versus males, whether smokers or non-smokers, are unknown, although there are epidemiological as well as biochemical studies indicating that estrogen may play a role in this difference (Stabile \& Siegfried 2003). Here, we report that lung adenocarcinoma cell lines from female, but not male patients proliferate in response to $\mathrm{E}_{2}$ and this proliferation is blocked by 4-OHT and ICI 182,780, indicating that the response is ER mediated. These results are similar to $\mathrm{E}_{2}, 4-\mathrm{OHT}$ and ICI 182,780 responses in MCF-7 breast cancer cells (Bowers et al. 2000). In addition to $\mathrm{E}_{2}$-induced cell proliferation, the cell lines from females, but not males, showed transcriptional activation of an ERE-luciferase reporter by endogenous $E R$ in response to $E_{2}$.

Surprisingly, despite the proliferative and transcriptional response to $E_{2}$ in female versus male adenocarcinoma cells, ER expression (as measured by three independent tests) was similar between the genders. Real-time PCR revealed that mRNA for $E R \beta$ in all the lung adenocarcinoma cell lines was expressed at a level comparable with that of ER $\beta$ in MCF-7 cells and at a higher level than ER $\alpha$ in MCF-7 or any of the normal or neoplastic lung cells. There was no gender-dependent difference in ER $\alpha$ or ER $\beta$ mRNA expression levels between adenocarcinoma cells. Specific $\left[{ }^{3} \mathrm{H}\right] \mathrm{E}_{2}$ binding and the estimated expression levels of full-length ER $\alpha$ and ER $\beta$, based on immunoblotting with known concentrations of rhER $\alpha$ or $\operatorname{rhER} \beta$ as calibrators, were also similar between the genders. Thus, a difference in ER expression does not appear to be the mechanism accounting for the proliferative activity of $E_{2}$ and the anti-proliferative activity of 4-OHT and ICI 182,780 in lung adenocarcinoma cells from females versus males. Accordingly, we speculate that the expression or activity of some critical component(s) of the ER signaling pathways, e.g. coactivators and or corepressors, may be different between lung adenocarcinomas from male and female patients. Indeed, we observed that the average expression of the coactivator PBP/TRAP220/DRIP205, which is an essential ER coactivator that interacts directly with $\mathrm{ER} \alpha$ and components of the RNA polymerase II holoenzyme/mediator complex (Burakov et al. 2000, 2002, Shang et al. 2000, Kang et al. 2002, Saville et al. 2002, Lee et al. 2005, Zhang et al. 2005), was higher in lung adenocarcinoma cell lines from females than males and higher in the lung cancer cell lines compared with NHBE, NF1604 or MCF-7 cells. PBP/TRAP220/ DRIP205 was reported to be over-expressed in breast tumors and cell lines relative to normal human mammary gland (Zhu et al. 1999) but, to our knowledge, no one has evaluated its expression in lung adenocarcinoma. There is one report on coactivator GRIP1 (TIF2) expression in NSCLC cell lines showing that GRIP1 is expressed in A549 adenocarcinoma and 128-88T squamous cell carcinoma cell lines, but not in the 201T adenocarcinoma cell line (Hershberger et al. 2005). Since there are currently 49 known ER-interacting coactivators and 18 known ER-interacting corepressors (Klinge 2000, Smith \& O'Malley 2004), more experiments will be needed to address the possible different expression of ER coregulators in 
lung adenocarcinomas from male and female patients. Additionally, non-genomic pathways activated by ER ligands, such as the mitogen-activated protein kinase (MAPK)/epidermal growth factor receptor (EGFR) pathway, recently described as being $\mathrm{E}_{2}$ activated in the 201T (Stabile et al. 2005) and H23 (Pietras et al. 2005) lung adenocarcinoma cell lines from males, may also play a role in the estrogen responses detected in our study. Clearly, this possibility will be another important avenue of further investigation.

We compared the ER expression in lung adenocarcinoma to that measured in other studies of lung cancer and ER expression in breast cancer. To our knowledge, there is only one report that estimated ER concentration in the $\mathrm{H} 23$ adenocarcinoma cell line by $\left[{ }^{3} \mathrm{H}\right] \mathrm{E}_{2}$ binding to be $1.9 \mathrm{fmol} / \mu \mathrm{g}$ cell membrane protein (Pietras et al. 2005) and no reports of ER concentration in extracts from human lung tumors or lung cancer cell lines. In the lung adenocarcinoma cells, ER $\alpha$ expression from Western blot estimation using baculovirus-expressed $\mathrm{ER} \alpha$ as a calibrator were an average of 1.54 and $1.61 \mathrm{fmol} / \mu \mathrm{g}$ for males and females respectively. The values for ER $\beta$ were the 3.98 and $4.02 \mathrm{fmol} / \mu \mathrm{g}$ for males and females respectively. In contrast, $\left[{ }^{3} \mathrm{H}\right] \mathrm{E}_{2}$ binding assays gave total ER concentration as 0.14 and $0.11 \mathrm{fmol} / \mu \mathrm{g} \mathrm{WCE}$ for males and females respectively. Western blot analysis gave an estimate of $2 \mathrm{fmol} \mathrm{ER} \alpha / \mu \mathrm{g} \mathrm{MCF}-7$ WCE using baculovirus ER $\alpha$ as a standard. However, our HAP assay data indicate an average $\left[{ }^{3} \mathrm{H}\right] \mathrm{E}_{2}$ binding value of $0.15 \mathrm{fmol} / \mu \mathrm{g}$ WCE, which closely agrees with the published value of $0.16 \mathrm{fmol} \mathrm{ER/ \mu g} \mathrm{NE} \mathrm{(Chaloupka}$ et al. 1992). This value agrees with those for the NE from lung adenocarcinoma cells (Fig. 3). ER expression, as measured by $\left[{ }^{3} \mathrm{H}\right] \mathrm{E}_{2}$ binding, in breast tumors ranges between $10-1000 \mathrm{fmol} / \mathrm{mg}$ nuclear protein $(0.01-1 \mathrm{fmol} / \mu \mathrm{g})$ and $2-3 \mathrm{pmol} / \mathrm{mg}(2-3 \mathrm{fmol} / \mu \mathrm{g})$ cytosolic protein (Forster et al. 2004). The latter values are greater than the lung adenocarcinoma cells and agree with the higher $\left[{ }^{3} \mathrm{H}\right] \mathrm{E}_{2}$ binding that we detected in the MCF-7 cells.

We suggest that the difference between the western and $\left[{ }^{3} \mathrm{H}\right] \mathrm{E}_{2}$ binding estimates of ER concentration indicate that not all of the expressed ER protein is able to bind ligand. From these values, it appears that only $10 \%$ of ER binds $\left[{ }^{3} \mathrm{H}\right] \mathrm{E}_{2}$. Whether this is the result of cell extraction and the assay techniques or a biological property of ER remains to be determined.

Our results in lung adenocarcinoma differ from breast cancer where progression to estrogen independence and anti-estrogen resistance is often associated with decreased ER $\alpha$ expression (Yang et al. 2001); the results also differ from endometrial and ovarian cancer where the $E R \beta: E R \alpha$ ratio is decreased compared with the respective non-cancer tissues (Pujol et al. 1998, Fujimoto et al. 2000, Li et al. 2003). Moreover, $\mathrm{E}_{2}$ binding was higher in NEs compared with CEs, indicating that sequestration of ER outside the nucleus does not appear to be the cause of the lack of ER responses in the adenocarcinoma cells from males. Furthermore, gender had no apparent effect on $\mathrm{ER} \alpha$ or ER $\beta$ expression. ER $\beta$ expression was higher than ER $\alpha$ in all adenocarcinoma cell lines. These data agree with previous reports that ER $\beta$ expression was higher than ER $\alpha$ in A549 (Stabile et al. 2002, Hershberger et al. 2005) and H1435 (Mollerup et al. 2002) cell lines.

To our knowledge, the only report of $\mathrm{ER} \alpha$ and ER $\beta$ protein expression in normal human lung, by immunostaining, indicated overlapping as well as celltype-distinct bronchiolar expression of each subtype (Taylor \& Al-Azzawi 2000). There are only three reports evaluating the expression of $\mathrm{ER} \alpha$ and $\mathrm{ER} \beta$ proteins in lung adenocarcinoma tumors or cell lines, and these reports reached different conclusions, especially regarding $\mathrm{ER} \alpha$ expression (Omoto et al. 2001, Fasco et al. 2002, Hershberger et al. 2005). There are many more reports on ER $\alpha$ and ER $\beta$ mRNA expression in normal human lung and NSCLC by RT-PCR (Fasco et al. 2002, Mollerup et al. 2002, Radzikowska et al. 2002, Stabile et al. 2002). Notably, ER expression is highly variable between samples and laboratories, differences that are probably due to the technique employed and the method of sample preparation.

Although adenocarcinoma cells from females and males had comparable expression of ER $\beta$, the ER $\beta$ antagonist R,R-THC inhibited $\mathrm{E}_{2}$-induced cell proliferation selectively in the female cell lines. These cell lines did not have a lower ER $\alpha$ : ER $\beta$ ratio versus cells from males. Thus, the mechanism accounting for this observation is unknown. Clearly further experiments to ascertain the roles of $E R \alpha$ and $E R \beta$ in adenocarcinomas from female and male patients is warranted. The inhibition of $\mathrm{E}_{2}$-induced proliferation by $\mathrm{R}, \mathrm{R}$ THC was similar to that detected with ICI 182,780 , but less than that detected for 4-OHT, suggesting the possibility that ER $\beta$ as well as ER $\alpha$ may be involved in $\mathrm{E}_{2}$-induced cell replication in these cell lines.

4-OHT alone inhibited adenocarcinoma cell proliferation in cells from females, but the pure steroidal anti-estrogen ICI 182,780 alone inhibited only H1395 (female) proliferation. Both 4-OHT and ICI 182,780 inhibited $\mathrm{E}_{2}$-induced cell replication. In the two 
previous reports showing that ICI 182,780 inhibits $\mathrm{E}_{2^{-}}$ induced responses in $\mathrm{H} 23$ and $201 \mathrm{~T}$ cell lines, ICI 182,780 was not tested alone (Pietras et al. 2005, Stabile et al. 2005). Previous investigators have reported that, in addition to inhibiting $\mathrm{E}_{2}-\mathrm{ER}$ binding competitively, 4-OHT also inhibits protein kinase C (Gundimeda et al. 1996) and calmodulin-dependent cAMP phosphodiesterase (Colletta et al. 1994), but the mechanism for the inhibition of proliferation of the lung cancer cells seen with 4-OHT alone has not yet been determined.

Overall, we conclude that adenocarcinoma cell lines from males are not estrogen responsive, as measured by cell proliferation. Although 4-OHT inhibited the proliferation of $\mathrm{H} 1299$ and $\mathrm{H} 1792$ cell lines by 25\%, this inhibition is significantly less than that observed in the adenocarcinoma cell lines from females. Both H1299 and H1792 cell lines were from male smokers, whereas the $\mathrm{H} 23$ and A549 cell lines that were not inhibited by 4-OHT were from non-smokers. However, whether smoking increases sensitivity to 4-OHT and the mechanism for this response in these cells is unknown. The only common published markers for $\mathrm{H} 23$ and A549 are that both lines show low activation of the PI3K/Akt pathway (Kandasamy \& Srivastava 2002) and neither has EGFR mutations (Tracy et al. 2004). 4-OHT inhibits the mitogenic activity of EGF in breast cancer cells (Chalbos et al. 1993) but whether 4-OHT impacts EGFR activity in $\mathrm{H} 23$ and A549 or other lung adenocarcinoma cell lines is unknown. ER-EGFR cross-talk and 'non-genomic' or membrane-initiated $E_{2}$ action, characterized most extensively in endothelial cells (Klinge et al. 2005), has recently been reported to occur in NSCLC cell lines (Stabile et al. 2005). Further experiments will be required to examine the role of membrane-initiated (non-genomic) $\mathrm{E}_{2}$ signaling in lung adenocarcinoma and whether this contributes to gender-specific differences or the ability of 4-OHT to inhibit proliferation of the H1299 and H1792 cell lines from males.

This study is unique in not only examining ER $\alpha$ and ER $\beta$ expression and the effects of $E_{2}$ and antiestrogens on lung adenocarcinoma cell proliferation, but because we also characterized the transcriptional response of endogenous ER using an ERE-reporter assay, examined the effect of $E_{2}$ on the expression of two endogenous estrogen-responsive genes (PR and E-cadherin) and examined a critical coactivator of ER (i.e. PBP/TRAP220/DRIP205). The results of the transient transfection assays reflected results of the cell proliferation assays: NF1604 cells and the adenocarcinoma cell lines from males showed no $\mathrm{E}_{2}$-induced
ERE-driven luciferase activity whereas $\mathrm{E}_{2}$ induced, and concomitant 4-OHT or ICI 182,780 inhibited, the $\mathrm{E}_{2}$-induced luciferase activity in cells from females. Thus, despite expressing comparable ER $\alpha$ and ER $\beta$, cells from males did not show induction of ERE-driven luciferase activity in these transient transfection studies, indicating a lack of ER genomic function, i.e. transcriptional activation from an ERE, in these cells. We conclude that ER $\alpha$ or ER $\beta$ expression does not account for the differences in $\mathrm{E}_{2}$ proliferative or transcriptional responses in adenocarcinoma cells from male versus female patients. Although the average DRIP205 expression is higher in cell lines from females than males, we do not believe that DRIP205 is the only coregulator whose expression may differ between the cell lines or between genders. Further examination of ER coregulator expression in lung adenocarcinoma cell lines and tumor samples is a next logical step in our investigation of the mechanisms involved in gender differences in NSCLC.

In contrast, endogenous estrogen target gene expression did fully follow this pattern of female responsiveness. Although PR was expressed in all the adenocarcinoma cell lines, $\mathrm{E}_{2}$ induced $\mathrm{PR}$ only in two of the five cell lines from females, indicating a lack of full correlation between gender and $\mathrm{E}_{2}$-induced $\mathrm{PR}$ response. Similarly, although E-cadherin was recently reported to be a marker for $\mathrm{E}_{2}$ in NSCLC (Hershberger et al. 2005), we found that $\mathrm{E}_{2}$ did not stimulate E-cadherin expression in any of the adenocarcinoma cell lines. Clearly, a reasonable next step in our study will be to identify $E_{2}$-regulated genes in adenocarcinoma cell lines from females versus males.

There are a few reports demonstrating that androgen receptor (AR) is expressed in normal human lung and in SCC and NSCLC (Beattie et al. 1985, Kaiser et al. 1996, Wilson \& McPhaul 1996, Lin et al. 2004). Based on specific $\left[{ }^{3} \mathrm{H}\right]$ ligand binding assays, lung adenocarcinomas had twice as much ER as AR, i.e. 4.8 and $2.6 \mathrm{fmol} / \mathrm{mg}$ protein respectively (Beattie et al. 1985). However, to our knowledge, no one has compared AR expression or activity in lung tumors from men versus women. Activation of AR by dihydrotestosterone (DHT) was reported to inhibit $\mathrm{E}_{2}$-stimulated proliferation by ZR-75-1 breast cancer cells (Poulin et al. 1988), but the effect of DHT on lung adenocarcinoma cell lines is not well characterized. One recent study showed that DHT stimulated the proliferation of NCI-H1355 adenocarcinoma cells and that the cigarette smoke carcinogen $\mathrm{B}[\mathrm{a}] \mathrm{P}$ inhibited DHT-stimulated proliferation and AR expression in vitro (Lin et al. 2004). Interestingly, this cell line was derived from a male patient. Another logical set of 
experiments would be to examine AR expression and function in adenocarcinoma cell lines from male and female patients to determine if AR 'squelches' (Meyer et al. 1989), e.g. competes for limited coregulators, the activity of ER in the adenocarcinoma cells from male patients.

In summary, our studies suggest that the gender of a patient with lung adenocarcinoma may have an impact on the estrogen/anti-estrogen response of the tumor. The ability of ER antagonists 4-OHT and ICI 182,780, and the ER $\beta$-selective antagonist R,R$\mathrm{THC}$, to inhibit $\mathrm{E}_{2}$-induced proliferation of lung adenocarcinoma cells from females, but not males, despite similar expression of ER $\alpha$ and ER $\beta$, indicates the possible use of these agents to inhibit selectively tumor growth in female patients. There is currently a clinical trial at the University of Pittsburgh addressing whether a combination of ER and EGFR inhibitors (Faslodex and Iressa) may be effective in treating lung cancer, regardless of gender (Hershberger et al. 2005). Although ER $\alpha, E R \beta$ and E-cadherin do not appear to be useful biomarkers of estrogen responsiveness in lung adenocarcinoma cell lines, whether PR may be a biomarker in a subset of $E_{2} /$ anti-estrogen-responsive tumors, and whether it is female specific, remains to be determined. The higher DRIP205 expression detected in some of the lung adenocarcinoma cell lines from females may play a role in the greater estrogenic responses seen, but is unlikely to be the sole determinant of gender-specific differences in response. Identification of the precise molecular mechanisms involved in the gender-specific response of the adenocarcinoma cells to $E_{2}$ and anti-estrogens warrants further study.

\section{Acknowledgements}

We thank Dr John A Katzenellenbogen for providing the R,R-THC for this study. We thank Dr Michael Garabedian for providing the DRIP205 antibody and Dr Nalinie S Wickramasinghe for performing some of the HAP assays on MCF-7 cells. We thank Drs Barbara J. Clark and Richard E. Goldstein for their insightful comments on our manuscript.

\section{Funding}

This work was supported by grants from the Commonwealth of Kentucky Lung Cancer Research Program to WGM and CMK and by NIH RO1 DK 53220 and an Intramural Research Incentive Grant from the Office of the Senior Vice President for Research to CMK. A R B was supported by a summer medical student fellowship from the Summer Research Scholars Program, School of Medicine; K A R is supported by a pre-doctoral fellowship from NIH/NIEHS T32 ES011564; KA M is supported by pre-doctoral fellowship 315087B from the American Heart Association Ohio Valley Affiliate. $\mathrm{MOH}$ is supported by a grant from the Kentucky Biomedical Research Infrastructure Network (KBRIN) funded by NIH P20 RR16481. The authors declare that there is no conflict of interest that would prejudice the impartiality of this scientific work.

\section{References}

Barsalou A, Gao W, Anghel SI, Carriere J \& Mader S 1998 Estrogen response elements can mediate agonist activity of anti-estrogens in human endometrial Ishikawa cells. Journal of Biological Chemistry 273 17138-17146.

Beattie CW, Hansen NW \& Thomas PA 1985 Steroid receptors in human lung cancer. Cancer Research $\mathbf{4 5}$ 4206-4214.

Bowers JL, Tyulmenkov VV, Jernigan SC \& Klinge CM 2000 Resveratrol acts as a mixed agonist/antagonist for estrogen receptors alpha and beta. Endocrinology 141 3657-3667.

Boyle P, Maisonneuve P \& Autier P 2000 Update on cancer control in women. International Journal of Gynaecology and Obstetrics 70 263-303.

Burakov D, Wong CW, Rachez C, Cheskis BJ \& Freedman LP 2000 Functional interactions between the estrogen receptor and DRIP205, a subunit of the heteromeric DRIP coactivator complex. Journal of Biological Chemistry 275 20928-20934.

Burakov D, Crofts LA, Chang CP \& Freedman LP 2002 Reciprocal recruitment of DRIP/mediator and p160 coactivator complexes in vivo by estrogen receptor. Journal of Biological Chemistry 277 14359-14362.

Bustin SA 2002 Quantification of mRNA using realtime reverse transcription PCR (RT-PCR): trends and problems. Journal of Molecular Endocrinology 29 23-39.

Caltagirone S, Ranelletti FO, Rinelli A, Maggiano N, Colasante A, Musiani P, Aiello FB \& Piantelli M 1997 Interaction with type II estrogen binding sites and antiproliferative activity of tamoxifen and quercetin in human non-small-cell lung cancer. American Journal of Respiratory Cell Molecular Biology 17 51-59.

Chalbos D, Philips A, Galtier F \& Rochefort H 1993 Synthetic antiestrogens modulate induction of $\mathrm{pS} 2$ and cathepsin-D messenger ribonucleic acid by growth factors and adenosine $3^{\prime}, 5^{\prime}$-monophosphate in MCF7 cells. Endocrinology 133 571-576.

Chaloupka K, Krishnan V \& Safe S 1992 Polynuclear aromatic hydrocarbon carcinogens as antiestrogens in MCF-7 human breast cancer cells: role of the Ah receptor. Carcinogenesis 13 2233-2239. 
Choi I, Ko C, Park-Sarge O, Nie R, Hess RA, Graves C \& Katzenellenbogen BS 2001 Human estrogen receptor beta-specific monoclonal antibodies: characterization and use in studies of estrogen receptor beta protein expression in reproductive tissues. Molecular and Cellular Endocrinology 181 139-150.

Colletta AA, Benson JR \& Baum M 1994 Alternative mechanisms of action of anti-oestrogens. Breast Cancer Research and Treatment 31 5-9.

Coombes RC, Hall E, Gibson LJ, Paridaens R, Jassem J, Delozier T, Jones SE, Alvarez I, Bertelli G, Ortmann O et al. 2004 A randomized trial of exemestane after two to three years of tamoxifen therapy in postmenopausal women with primary breast cancer. New England Journal of Medicine 350 1081-1092.

Couse JF, Lindzey J, Grandien K, Gustafsson JA \& Korach KS 1997 Tissue distribution and quantitative analysis of estrogen receptor-alpha (ERalpha) and estrogen receptor-beta (ERbeta) messenger ribonucleic acid in the wild-type and ERalpha-knockout mouse. Endocrinology 138 4613-4621.

Croxtall JD, Emmas C, White JO, Choudhary Q \& Flower RJ 1994 Tamoxifen inhibits growth of oestrogen receptor-negative A549 cells. Biochemistry and Pharmacology 47 197-202.

Di Nunno L, Larsson LG, Rinehart JJ \& Beissner RS 2000 Estrogen and progesterone receptors in non-small cell lung cancer in 248 consecutive patients who underwent surgical resection. Archives of Pathology and Laboratory Medicine 124 1467-1470.

Fasco MJ, Hurteau GJ \& Spivack SD 2002 Genderdependent expression of alpha and beta estrogen receptors in human nontumor and tumor lung tissue. Molecular and Cellular Endocrinology 188 125-140.

Forster C, Kietz S, Hultenby K, Warner M \& Gustafsson J-A 2004 Characterization of the ER $\beta-/-$ mouse heart. PNAS 101 14234-14239.

Fujimoto J, Sakaguchi H, Aoki I, Khatun S, Toyoki H \& Tamaya T 2000 Steroid receptors and metastatic potential in endometrial cancers. Journal of Steroid Biochemistry and Molecular Biology 75 209-212.

Gatzemeier U, Groth G, Butts C, Van Zandwijk N, Shepherd F, Ardizzoni A, Barton C, Ghahramani P \& Hirsh V 2004 Randomized phase II trial of gemcitabinecisplatin with or without trastuzumab in HER2positive non-small-cell lung cancer. Annals of Oncology 15 19-27.

Ginzinger DG 2002 Gene quantification using real-time quantitative PCR: an emerging technology hits the mainstream. Experimental Hematology 30 503-512.

Greenlee RT, Murray T, Bolden S \& Wingo PA 2000 Cancer statistics, 2000. CA: A Cancer Journal for Clinicians 50 7-33.

Gundimeda U, Chen ZH \& Gopalakrishna R 1996 Tamoxifen modulates protein kinase $\mathrm{C}$ via oxidative stress in estrogen receptor-negative breast cancer cells. Journal of Biological Chemistry 271 13504-13514.
Hashimoto T, Tokuchi Y, Hayashi M, Kobayashi Y, Nishida K, Hayashi S, Ishikawa Y, Nakagawa K, Hayashi J \& Tsuchiya E 2000 Different subtypes of human lung adenocarcinoma caused by different etiological factors. Evidence from p53 mutational spectra. American Journal of Pathology 157 2133-2141.

Hershberger PA, Vasquez AC, Kanterewicz B, Land S, Siegfried JM \& Nichols M 2005 Regulation of endogenous gene expression in human non-small cell lung cancer cells by estrogen receptor ligands. Cancer Research 65 1598-1605.

Jordan VC \& Pappas SG 2003 Is tamoxifen the Rosetta stone for breast cancer? Journal of the National Cancer Institute 95 338-340.

Kaiser U, Hofmann J, Schilli M, Wegmann B, Klotz U, Wedel S, Virmani AK, Wollmer E, Branscheid D, Gazdar AF et al. 1996 Steroid-hormone receptors in cell lines and tumor biopsies of human lung cancer. International Journal of Cancer 67 357-364.

Kandasamy K \& Srivastava RK 2002 Role of the phosphatidylinositol 3'-kinase/PTEN/Akt kinase pathway in tumor necrosis factor-related apoptosis-inducing ligand-induced apoptosis in non-small cell lung cancer cells. Cancer Research 62 4929-4937.

Kang YK, Guermah M, Yuan CX \& Roeder RG 2002 The TRAP/Mediator coactivator complex interacts directly with estrogen receptors alpha and beta through the TRAP220 subunit and directly enhances estrogen receptor function in vitro. PNAS 99 2642-2647.

Klinge CM 2000 Estrogen receptor interaction with co-activators and co-repressors. Steroids $\mathbf{6 5}$ 227-251.

Klinge CM, Jernigan SC, Mattingly KA, Risinger KE \& Zhang J 2004 Estrogen response element-dependent regulation of transcriptional activation of estrogen receptors alpha and beta by coactivators and corepressors. Journal of Molecular Endocrinology 33 387-410.

Klinge CM, Blankenship KA, Risinger KE, Bhatnagar S, Noisin EL, Sumanasekera WK, Brey DM \& Keynton RS 2005 Resveratrol and estradiol rapidly activate MAPK signaling through estrogen receptors alpha and beta in endothelial cells. Journal of Biological Chemistry $\mathbf{2 8 0}$ 7460-7468.

Kuiper GG, Carlsson B, Grandien J, Enmark E, Haggblad J, Nilsson S \& Gustafsson J-A 1997 Comparison of the ligand binding specificity and transcript tissue distribution of estrogen receptors $\alpha$ and $\beta$. Endocrinology 138 863-870.

Kulakosky PC \& Klinge CM 2003 Maximizing production of estrogen receptor beta with the baculovirus expression system. Biotechniques 34 334-343.

Kulakosky PC, Jernigan SC, McCarty MA \& Klinge CM 2002 Response element sequence regulates estrogen receptor alpha and beta affinity and activity. Journal of Molecular Endocrinology 29 137-152. 
Kumar R \& Hung M-C 2005 Signaling intricacies take center stage in cancer cells. Cancer Research $652511-$ 2515.

Lee JE, Kim K, Sacchettini JC, Smith CV \& Safe S 2005 DRIP150 coactivation of estrogen receptor ${ }^{\alpha}$ in ZR-75 breast cancer cells is independent of LXXLL motifs. Journal of Biological Chemistry 280 8819-8830.

Li AJ, Baldwin RL \& Karlan BY 2003 Estrogen and progesterone receptor subtype expression in normal and malignant ovarian epithelial cell cultures. American Journal of Obstetrics and Gynecology 189 22-27.

Liao ML, Wang JH, Wang HM, Ou AQ, Wang XJ \& You WQ 1996 A study of the association between squamous cell carcinoma and adenocarcinoma in the lung, and history of menstruation in Shanghai women, China. Lung Cancer 14 Suppl 1 S215-221.

Lin P, Chang JT, Ko JL, Liao SH \& Lo WS 2004 Reduction of androgen receptor expression by benzo[alpha]pyrene and 7,8-dihydro-9,10-epoxy-7,8,9,10tetrahydrobenzo[alpha]pyrene in human lung cells. Biochemical Pharmacology 67 1523-1530.

Lindberg MK, Moverare S, Skrtic S, Gao H, DahlmanWright K, Gustafsson JA \& Ohlsson C 2003 Estrogen receptor (ER)-beta reduces ERalpha-regulated gene transcription, supporting a 'ying yang' relationship between ERalpha and ERbeta in mice. Molecular Endocrinology 17 203-208.

McGuire WL, Clark GM, Dressler LG \& Owens MA 1986 Role of steroid hormone receptors as prognostic factors in primary breast cancer. $N C I$ Monographs 19-23.

Marsaud V, Gougelet A, Maillard S \& Renoir JM 2003 Various phosphorylation pathways, depending on agonist and antagonist binding to endogenous estrogen receptor alpha (ERalpha), differentially affect ERalpha extractability, proteasome-mediated stability, and transcriptional activity in human breast cancer cells. Molecular Endocrinology 17 2013-2027.

Merot Y, Metivier R, Penot G, Manu D, Saligaut C, Gannon F, Pakdel F, Kah O \& Flouriot G 2004 The relative contribution exerted by AF-1 and AF-2 transactivation functions in estrogen receptor $\alpha$ transcriptional activity depends upon the differentiation stage of the cell. Journal of Biological Chemistry 279 26184-26191.

Meyer ME, Gronemeyer H, Turcotte B, Bocquel MT, Tasset D \& Chambon P 1989 Steroid hormone receptors compete for factors that mediate their enhancer function. Cell 57 433-442.

Mollerup S, Ryberg D, Hewer A, Phillips DH \& Haugen A 1999 Sex differences in lung CYP1A1 expression and DNA adduct levels among lung cancer patients. Cancer Research 59 3317-3320.

Mollerup S, Jorgensen K, Berge G \& Haugen A 2002 Expression of estrogen receptors alpha and beta in human lung tissue and cell lines. Lung Cancer 37 153-159.

Moore KA, Mery CM, Jaklitsch MT, Estocin AP, Bueno R, Swanson SJ, Sugarbaker DJ \& Lukanich JM 2003 Menopausal effects on presentation, treatment, and survival of women with non-small cell lung cancer. Annals of Thoracic Surgery 76 1789-1795.

Oesterreich S, Deng W, Jiang S, Cui X, Ivanova M, Schiff R, Kang K, Hadsell DL, Behrens J \& Lee AV 2003 Estrogen-mediated down-regulation of E-cadherin in breast cancer cells. Cancer Research 63 5203-5208.

Okudela K, Hayashi H, Ito T, Yazawa T, Suzuki T, Nakane Y, Sato H, Ishi H, KeQin X, Masuda A et al. 2004 K-ras gene mutation enhances motility of immortalized airway cells and lung adenocarcinoma cells via Akt activation: possible contribution to non-invasive expansion of lung adenocarcinoma. American Journal of Pathology 164 91-100.

Omoto Y, Kobayashi Y, Nishida K, Tsuchiya E, Eguchi H, Nakagawa K, Ishikawa Y, Yamori T, Iwase H, Fujii Y et al. 2001 Expression, function, and clinical implications of the estrogen receptor beta in human lung cancers. Biochemistry and Biophysics Research Communications 285 340-347.

Ouellette MM, McDaniel LD, Wright WE, Shay JW \& Schultz RA 2000 The establishment of telomeraseimmortalized cell lines representing human chromosome instability syndromes. Human and Molecular Genetics 9 403-411.

Paruthiyil S, Parmar H, Kerekatte V, Cunha GR, Firestone GL \& Leitman DC 2004 Estrogen receptor beta inhibits human breast cancer cell proliferation and tumor formation by causing a $\mathrm{G}(2)$ cell cycle arrest. Cancer Research 64 423-428.

Patel JD 2005 Lung cancer in women. Journal of Clinical Oncology 23 3212-3218.

Patel JD, Bach PB \& Kris MG 2004 Lung cancer in US women: a contemporary epidemic. Journal of the American Medical Association 291 1763-1768.

Patrone C, Cassel TN, Pettersson K, Piao Y-S, Cheng G, Ciana P, Maggi A, Warner M, Gustafsson J-A \& Nord M 2003 Regulation of postnatal lung development and homeostasis by estrogen receptor $\beta$. Molecular and CellularBiology 23 8542-8552.

Pegram MD, Lipton A, Hayes DF, Weber BL, Baselga JM, Tripathy D, Baly D, Baughman SA, Twaddell T, Glaspy JA et al. 1998 Phase II study of receptorenhanced chemosensitivity using recombinant humanized anti-p185HER2/neu monoclonal antibody plus cisplatin in patients with HER2/neu-overexpressing metastatic breast cancer refractory to chemotherapy treatment. Journal of Clinical Oncology 16 2659-2671.

Pietras RJ, Marquez DC, Chen HW, Tsai E, Weinberg O \& Fishbein M 2005 Estrogen and growth factor receptor interactions in human breast and non-small cell lung cancer cells. Steroids 70 372-381. 
Pineda Torra I, Freedman LP \& Garabedian MJ 2004 Identification of DRIP205 as a coactivator for the farnesoid X receptor. Journal of Biological Chemistry 279 36184-36191.

Planas-Silva MD, Shang Y, Donaher JL, Brown M \& Weinberg RA 2001 AIB1 enhances estrogen-dependent induction of cyclin d1 expression. Cancer Research 61 $3858-3862$.

Poulin R, Baker D \& Labrie F 1988 Androgens inhibit basal and estrogen-induced cell proliferation in the ZR-75-71 human breast cancer cell line. Breast Cancer Research and Treatment 12 213-225.

Pujol P, Rey JM, Nirde P, Roger P, Gastaldi M, Laffargue F, Rochefort H \& Maudelonde T 1998 Differential expression of estrogen receptor-alpha and -beta messenger RNAs as a potential marker of ovarian carcinogenesis. Cancer Research 58 5367-5373.

Radzikowska E, Langfort R \& Giedronowicz D 2002 Estrogen and progesterone receptors in non small cell lung cancer patients. Annals of Thoracic Cardiovascular Surgery 8 69-73.

Rubanyi GM, Freay AD, Kauser K, Sukovich D, Burton G, Lubahn DB, Couse JF, Curtis SW \& Korach KS 1997 Vascular estrogen receptors and endothelium-derived nitric oxide production in the mouse aorta. Gender difference and effect of estrogen receptor gene disruption. Journal of Clinical Investigation 99 2429-2437.

Saville B, Poukka H, Wormke M, Janne OA, Palvimo JJ, Stoner M, Samudio I \& Safe S 2002 Cooperative coactivation of estrogen receptor alpha in ZR-75 human breast cancer cells by SNURF and TATA-binding protein. Journal of Biological Chemistry 277 2485-2497.

Schabath MB, Wu X, Vassilopoulou-Sellin R, Vaporciyan AA \& Spitz MR 2004 Hormone replacement therapy and lung cancer risk: a case-control analysis. Clinical Cancer Research 10 113-123.

Scobie GA, Macpherson S, Millar MR, Groome NP, Romana PG \& Saunders PT 2002 Human oestrogen receptors: differential expression of ERalpha and beta and the identification of ERbeta variants. Steroids 67 985-992.

Shang Y, Hu X, DiRenzo J, Lazar MA \& Brown M 2000 Cofactor dynamics and sufficiency in estrogen receptorregulated transcription. Cell $103843-852$.

Shields PG 2000 Epidemiology of tobacco carcinogenesis. Current Oncology Reports 2 257-262.

Siegfried JM 2001 Women and lung cancer: does oestrogen play a role? Lancet Oncology 2 506-513.

Smith CL \& O'Malley BW 2004 Coregulator function: a key to understanding tissue specificity of selective receptor modulators. Endocrine Reviews 25 45-71.

Stabile LP \& Siegfried JM 2003 Sex and gender differences in lung cancer. Journal of Gender Specific Medicine 6 $37-48$.

Stabile LP, Davis AL, Gubish CT, Hopkins TM, Luketich JD, Christie N, Finkelstein S \& Siegfried JM 2002 Human non-small cell lung tumors and cells derived from normal lung express both estrogen receptor alpha and beta and show biological responses to estrogen. Cancer Research 62 2141-2150.

Stabile LP, Lyker JS, Gubish CT, Zhang W, Grandis JR \& Siegfried JM 2005 Combined targeting of the estrogen receptor and the epidermal growth factor receptor in non-small cell lung cancer shows enhanced antiproliferative effects. Cancer Research $\mathbf{6 5}$ 1459-1470.

Su JM, Hsu HK, Chang H, Lin SL, Chang HC, Huang MS \& Tseng HH 1996 Expression of estrogen and progesterone receptors in non-small-cell lung cancer: immunohistochemical study. Anticancer Research 16 3803-3806.

Sun J, Meyers MJ, Fink BE, Rajendran R, Katzenellenbogen JA \& Katzenellenbogen BS 1999 Novel ligands that function as selective estrogens or antiestrogens for estrogen receptor-alpha or estrogen receptor-beta. Endocrinology 140 800-804.

Taioli E \& Wynder EL 1994 Re: endocrine factors and adenocarcinoma of the lung in women. Journal of the National Cancer Institute 86 869-870.

Taylor AH \& Al-Azzawi F 2000 Immunolocalisation of oestrogen receptor beta in human tissues. Journal of Molecular Endocrinology 24 145-155.

Thomas PB, Risinger KE \& Klinge CM 2003 Identification of estrogen receptor beta expression in Chinese hamster ovary $(\mathrm{CHO})$ cells and comparison of estrogen-responsive gene transcription in cells adapted to serum-free media. Journal of Steroid Biochemistry and Molecular Biology 86 41-55.

Tracy S, Mukohara T, Hansen M, Meyerson M, Johnson BE \& Janne PA 2004 Gefitinib induces apoptosis in the EGFRL858R non-small-cell lung cancer cell line H3255. Cancer Research 64 7241-7244.

Tyulmenkov VT, Jernigan SC \& Klinge CM 2000 Comparison of transcriptional synergy of estrogen receptors alpha and beta from multiple tandem estrogen response elements. Molecular and Cellular Endocrinology $165151-161$.

Williams MD \& Sandler AB 2001 The epidemiology of lung cancer. Cancer Treament and Research 105 31-52.

Wilson CM \& McPhaul MJ 1996 A and B forms of the androgen receptor are expressed in a variety of human tissues. Molecular and Cellular Endocrinology $12051-57$

Wolff MS, Collman GW, Barrett JC \& Huff JJ 1996 Breast cancer and environmental risk factors: epidemiological and experimental findings. Annual Reviews in Pharmacology and Toxicology 36 573-596.

Yang X, Phillips DL, Ferguson AT, Nelson WG, Herman JG \& Davidson NE 2001 Synergistic activation of functional estrogen receptor (ER)-alpha by DNA methyltransferase and histone deacetylase inhibition in human ER-alpha-negative breast cancer cells. Cancer Research 61 7025-7029. 
Zhang X, Jeyakumar M, Petukhov S \& Bagchi MK 1998 A nuclear receptor corepressor modulates transcriptional activity of antagonist-occupied steroid hormone receptor. Molecular Endocrinology 12 513-524.

Zhang X, Krutchinsky A, Fukuda A, Chen W, Yamamura S, Chait BT \& Roeder RG 2005 MED1/TRAP220 exists predominantly in a TRAP/mediator subpopulation enriched in RNA polymerase II and is required for ER-mediated transcription. Molecular Cell 19 89-100.

Zhu Y, Qi C, Jain S, Le Beau MM, Espinosa R 3rd, Atkins GB, Lazar MA, Yeldandi AV, Rao MS \& Reddy JK 1999 Amplification and overexpression of peroxisome proliferator-activated receptor binding protein (PBP/PPARBP) gene in breast cancer. PNAS 96 10848-10853. 